\title{
Thermodynamic Properties of Barium-Bismuth Alloys Determined by Emf Measurements
}

Timothy Lichtenstein ${ }^{1}$, Nathan Smith $^{1}$, Jarrod Gesualdi ${ }^{1}$, Kuldeep $\operatorname{Kumar}^{1}$, Hojong Kim ${ }^{1 *}$

${ }^{1}$ Materials Science and Engineering, The Pennsylvania State University, 406 Steidle Building, University Park, PA 16802, United States

\section{Corresponding Author:}

*E-mail: huk29@psu.edu. Tel: 814-865-3117. Fax: 814-865-2917

KEYWORDS: Barium-Bismuth alloys, Emf method, Thermodynamic properties, Barium-

Bismuth phase diagram 


\begin{abstract}
Thermodynamic properties of Ba-Bi alloys, including the activity, partial molar entropy and enthalpy, were determined using the electromotive force (emf) technique for fourteen compositions, $x_{\mathrm{Ba}}=0.05-0.80$. Emf measurements were performed at ambient pressure using a $\mathrm{Ba}(\mathrm{s})\left|\mathrm{CaF}_{2}-\mathrm{BaF}_{2}\right| \mathrm{Ba}$ (in $\left.\mathrm{Bi}\right)$ or $\mathrm{Ba}-\mathrm{Bi}\left(x_{\mathrm{Ba}}=0.05\right)\left|\mathrm{CaF}_{2}-\mathrm{BaF}_{2}\right| \mathrm{Ba}$ (in $\left.\mathrm{Bi}\right)$ electrochemical cells at $723-1073 \mathrm{~K}$. At $773 \mathrm{~K}$, activity values of $\mathrm{Ba}$ were as low as $6.6 \times 10^{-16}$ at mole fraction $x_{\mathrm{Ba}}=$ 0.05 and approached unity for mole fractions $x_{\mathrm{Ba}} \geq 0.80$. Stable emf values were observed at mole fractions $x_{\mathrm{Ba}}=0.05-0.25$, exhibiting less than a $5 \mathrm{mV}$ difference between the heating and cooling cycles. Mole fractions $x_{\mathrm{Ba}} \geq 0.30$ exhibited increased hysteresis or had an unexpected emf profile due to the formation of metastable phases such as $\mathrm{Bi}$ and $\mathrm{Ba}_{5} \mathrm{Bi}_{3}$, confirmed by $\mathrm{X}$-ray diffraction. The Ba-Bi alloys were further characterized using differential scanning calorimetry over the entire composition range. Based on these data, a revised Ba-Bi binary phase diagram is proposed.
\end{abstract}




\section{INTRODUCTION}

Thermochemical properties of binary $\mathrm{Ba}-\mathrm{Bi}$ alloys were investigated using the electromotive force (emf) technique to assess the viability of $\mathrm{Bi}$ electrodes in separating $\mathrm{Ba}$ species from molten salt electrolytes. Recently, Kim et al. investigated the electrochemical properties of bismuth electrodes in a $\mathrm{BaCl}_{2}-\mathrm{LiCl}-\mathrm{CaCl}_{2}-\mathrm{NaCl}$ (16-29-35-20 mol\%) electrolyte at 773-973 K. They identified Ba to be preferentially deposited over $\mathrm{Na}$, Ca or Li due to Ba having the strongest atomic interactions with $\mathrm{Bi}$, i.e. the lowest thermodynamic activity values of $\mathrm{Ba}$ in the Bi metal among alkali/alkaline-earth constituents [1,2].

Delcet et al. determined the thermodynamic properties of $\mathrm{Ba}-\mathrm{Bi}$ alloys up to $x_{\mathrm{Ba}}=0.50$ by coulometric titration using a single-crystal $\mathrm{BaF}_{2}$ electrolyte at $1123 \mathrm{~K}$. The activity values of $\mathrm{Ba}$ in $\mathrm{Bi}$ were as low as $2 \times 10^{-12}$ at $x_{\mathrm{Ba}}=0.05$; however, they reported that the results were not accurate due to uncertainty in Ba compositions (up to 3 mol\%) during the coulometric titration [3]. Pure Ba metal is highly reactive and well known to have a high solubility in its own halide salts (e.g., $\sim 15 \mathrm{~mol} \%$ in $\mathrm{BaCl}_{2}$ at $1163 \mathrm{~K}$ ) [4]; barium metal dissolved in the halide electrolyte can promote electronic conduction through the electrolyte and prevent accurate compositional accounting by coulometric titration using halide electrolytes.

In this work, a solid-state binary $\mathrm{CaF}_{2}-\mathrm{BaF}_{2}(97-3 \mathrm{~mol} \%)$ electrolyte was employed to determine the emf values of Ba-Bi alloys at fixed compositions over 723-1073 K. In the binary $\mathrm{CaF}_{2}-\mathrm{BaF}_{2}$ system, $\mathrm{CaF}_{2}$ is more stable than $\mathrm{BaF}_{2}$ due to having a more negative potential versus the $\mathrm{F}^{-} / \mathrm{F}_{2}$ redox couple, implying barium ions are the more electroactive species in the $\mathrm{CaF}_{2}-\mathrm{BaF}_{2}$ electrolyte. For example, at $800 \mathrm{~K}$ the standard electrode potential is $-5.65 \mathrm{~V}$ for $\mathrm{Ca}^{2+} / \mathrm{Ca}$ and $-5.58 \mathrm{~V}$ for $\mathrm{Ba}^{2+} / \mathrm{Ba}$, calculated using the Nernst equation and the standard free energies of formation for $\mathrm{CaF}_{2}$ and $\mathrm{BaF}_{2}$ [5]. Utilizing the relatively high ionic conductivity of $\mathrm{CaF}_{2}(\sim 1.5 \times$ 
$10^{-3} \mathrm{~S} \mathrm{~cm}^{-1}$ at $1073 \mathrm{~K}$ ) [6] and higher stability than pure $\mathrm{BaF}_{2}$, the binary $\mathrm{CaF}_{2}-\mathrm{BaF}_{2}$ electrolyte will allow for accurate emf measurements of Ba-Bi alloys using the electrochemical cell:

$$
\left.\mathrm{Ba}(\mathrm{s})\left|\mathrm{CaF}_{2}-\mathrm{BaF}_{2}\right| \mathrm{Ba} \text { (in } \mathrm{Bi}\right)
$$

where pure $\mathrm{Ba}$ is the reference electrode $(\mathrm{RE})$, solid $\mathrm{CaF}_{2}-\mathrm{BaF}_{2}$ is the electrolyte, and $\mathrm{Ba}-\mathrm{Bi}$ alloys are the working electrodes (WE). Considering that $\mathrm{CaF}_{2}-\mathrm{BaF}_{2}$ is a fluoride-ion conducting electrolyte [6], the half-cell reactions are

$$
\begin{array}{ll}
\text { WE: } & \mathrm{BaF}_{2}(\mathrm{~s})+2 \mathrm{e}^{-}=\mathrm{Ba}(\text { in } \mathrm{Bi})+2 \mathrm{~F}^{-} \\
\text {RE: } & \mathrm{BaF}_{2}(\mathrm{~s})+2 \mathrm{e}^{-}=\mathrm{Ba}(\mathrm{s})+2 \mathrm{~F}^{-}
\end{array}
$$

and the overall cell reaction is

$$
\text { Overall: } \quad \mathrm{Ba}(\mathrm{s})=\mathrm{Ba}(\text { in } \mathrm{Bi}) \text {. }
$$

For this cell reaction, the change in partial molar Gibbs free energy of barium, $\Delta \bar{G}_{\mathrm{Ba}}$, is given by:

$$
\Delta \bar{G}_{\mathrm{Ba}}=\bar{G}_{\mathrm{Ba}(\mathrm{in} \mathrm{Bi})}-G_{\mathrm{Ba}(\mathrm{s})}^{0}=R T \ln a_{\mathrm{Ba}(\mathrm{in} \mathrm{Bi})}
$$

where $\bar{G}_{\mathrm{Ba}(\mathrm{in} \mathrm{Bi})}$ is the partial molar Gibbs free energy of barium in bismuth, $G_{\mathrm{Ba}(\mathrm{s})}^{0}$ is the standard Gibbs free energy of pure barium, $R$ is the ideal gas constant, $T$ is the temperature, and $a_{\mathrm{Ba}(\mathrm{in} \mathrm{Bi})}$ is the activity of barium in bismuth, referred to as $a_{\mathrm{Ba}}$ moving forward. By applying the Nernst equation $\left(\Delta \bar{G}_{\mathrm{Ba}}=-z F E_{\text {cell }}\right)$ to equation (5), the measured cell emf, $E_{\text {cell, }}$ is related to the change in partial molar Gibbs free energy of barium by

$$
E_{\text {cell }}=-\frac{\Delta \bar{G}_{\mathrm{Ba}}}{z F}=-\frac{R T}{z F} \ln a_{\mathrm{Ba}}
$$

where $F$ is the Faraday constant and $z$ is the number of electrons exchanged in the half-cell reactions $(z=2)$. 
where the reference electrode is denoted as underlined. The cell potential $E_{\mathrm{I}}$ of this electrochemical cell is

$$
E_{\mathrm{I}}=-\frac{R T}{2 F} \ln \left(\frac{a_{\mathrm{Ba}}}{a_{\mathrm{Ba}}^{*}}\right)
$$

where $a_{\mathrm{Ba}}^{*}$ is the activity at mole fraction $x_{\mathrm{Ba}}=0.05$.

In separate experiments, the electrode potential of the $\mathrm{Ba}-\mathrm{Bi}$ alloy at $x_{\mathrm{Ba}}=0.05$ was determined against pure $\mathrm{Ba}$, using the following cell:

$$
\text { Cell type II: } \underline{\mathrm{Ba}(\mathrm{s})}\left|\mathrm{CaF}_{2}-\mathrm{BaF}_{2}\right| \mathrm{Ba}-\mathrm{Bi}\left(x_{\mathrm{Ba}}=0.05\right)
$$

where the cell potential $E_{\mathrm{II}}$ is

$$
E_{\mathrm{II}}=-\frac{R T}{2 F} \ln a_{\mathrm{Ba}}^{*}
$$

Then, the summation of these two cell potentials $\left(E_{\mathrm{I}}+E_{\mathrm{II}}\right)$ results in the cell potential $\left(E_{\text {cell }}\right)$ of Ba-Bi alloys relative to pure $\mathrm{Ba}$ according to:

$$
E_{\text {cell }}=E_{\mathrm{I}}+E_{\mathrm{II}}=-\frac{R T}{2 F} \ln a_{\mathrm{Ba}} .
$$

In analyzing the thermodynamic properties of $\mathrm{Ba}-\mathrm{Bi}$ alloys, emf measurements were corroborated using powder X-ray diffraction (XRD) and differential scanning calorimetry (DSC) to determine the relevant crystal structures and phase transition temperatures for each alloy 
composition. These data were used to construct a revised Ba-Bi phase diagram over the full composition range, which includes the new phases of $\mathrm{Ba}_{11} \mathrm{Bi}_{10}, \mathrm{Ba}_{4} \mathrm{Bi}_{3}$, and $\mathrm{Ba}_{2} \mathrm{Bi}$.

\section{EXPERIMENTAL}

\subsection{Fabrication and assembly of electrochemical cell components}

Synthesis of $\mathbf{C a F}_{2}-\mathbf{B a F}_{2}$ electrolyte: Binary $\mathrm{CaF}_{2}-\mathrm{BaF}_{2}(97-3 \mathrm{~mol} \%)$ electrolyte for emf measurements was prepared by mixing the appropriate amounts of $\mathrm{BaF}_{2}(99.999 \%$, Sigma Aldrich, Stock No. 652458) and $\mathrm{CaF}_{2}$ (99.5\%, Alfa Aesar, Stock No. 11055) powders. Approximately $500 \mathrm{~g}$ of the binary mixture was added with $40 \mathrm{~g}$ of polyvinyl alcohol as binder, $20 \mathrm{~g}$ of polyethylene glycol plasticizer, and $1 \mathrm{~L}$ of isopropyl alcohol. The mixture was ballmilled using yttria-stabilized zirconia media ( $3 \mathrm{~mm}$ diameter, TOSOH USA) for $24 \mathrm{~h}$ and then dried in air.

About $130 \mathrm{~g}$ of the ball-milled, dry powder was uniaxially pressed at $30 \mathrm{MPa}$ into a green pellet (75 mm diameter and $17 \mathrm{~mm}$ thickness). Seven wells (each with $11.2 \mathrm{~mm}$ diameter and 12 mm depth) were drilled into the green pellet: one in the center for a thermocouple and six wells for Ba-Bi alloy electrodes evenly spaced about $25.4 \mathrm{~mm}$ from the center (Figure 1). The green pellet was heated in a box furnace in air at $393 \mathrm{~K}$ for $12 \mathrm{~h}$ at $5 \mathrm{~K} \mathrm{~min}^{-1}$ to remove moisture, at $823 \mathrm{~K}$ for $12 \mathrm{~h}$ at $2.5 \mathrm{~K} \mathrm{~min}^{-1}$ to burn out organic binder and plasticizer, and at $1273 \mathrm{~K}$ for $3 \mathrm{~h}$ at $5 \mathrm{~K} \mathrm{~min}^{-1}$ to sinter. Similarly, electrolyte caps were fabricated from $\sim \mathrm{g}$ of the mixture (19 mm diameter and $10 \mathrm{~mm}$ height) with a $1 \mathrm{~mm}$ center hole and sintered. During the final cell assembly, these electrolyte caps were placed on top of the electrode wells to minimize the cross contamination between the electrodes through vapor-phase transport at elevated temperatures.

\section{[Figure 1]}


Fabrication of Ba-Bi alloy electrodes: $\mathrm{Ba}-\mathrm{Bi}$ alloys were fabricated using a laboratory arc-melter (MAM1, Edmund Bühler GmbH). Barium (99.2\%, Alfa Aesar, Stock No. 00653) and bismuth (99.999\%, Sigma Aldrich, Stock No. 556130) pieces were weighed in appropriate quantities in an argon-filled glovebox $\left(\mathrm{O}_{2}<0.5 \mathrm{ppm}\right.$ and $\left.\mathrm{H}_{2} \mathrm{O}<1.5 \mathrm{ppm}\right)$ and arc-melted together under an inert argon atmosphere. Ba-Bi alloys were machined into cylindrical shapes with approximate dimensions of $10 \mathrm{~mm}$ diameter and $7 \mathrm{~mm}$ height with a $\sim 2 \mathrm{~mm}$ center hole to insert a tungsten electrical lead during electrochemical cell assembly. At the beginning of emf measurements, the cell assembly was held at $1073 \mathrm{~K}$ to melt alloy electrodes and to establish stable physical contact with the electrolyte and the tungsten electrical lead.

Ba-Bi alloys at mole fractions $x_{\mathrm{Ba}}=0.45-0.55$ were too brittle to fabricate in a cylindrical shape and stable electrical contact was difficult to establish due to their high melting temperatures (> $1043 \mathrm{~K}$ ). Instead, these alloys were induction melted on top of a boron nitride plate using an induction heater (IH15A-2T, Across International), custom-installed inside the glovebox. In this case, the tungsten electrical lead was immersed into the molten metal pool, and then the alloys were cooled while maintaining electrical contact with the tungsten wire. Similarly, electrical contact between the pure barium metal and the tungsten lead wire was established using the induction heater due to the high reactivity of molten Ba with the electrolyte.

Electrochemical cell assembly: The electrochemical cell (Figure 1) was assembled inside an argon-filled glovebox to minimize reaction of the electrodes with oxygen and moisture. The synthesized $\mathrm{CaF}_{2}-\mathrm{BaF}_{2}$ electrolyte was placed in an alumina crucible $(8.2 \mathrm{~cm}$ diameter and 3.0 cm height, AdValue Technology, Stock No. AL-4120) with the alloy electrodes in the electrolyte wells, and tungsten electrical leads (1mm diameter and $46 \mathrm{~cm}$ length) inserted through the stainless steel test chamber, through insulating alumina sheaths, through the electrolyte caps, and 
into the Ba-Bi alloy electrodes. The test chamber was sealed inside the glovebox, removed from the glovebox, and transferred into a crucible furnace.

\subsection{Emf measurements}

For electrochemical measurements, the test chamber was evacuated to less than $0.7 \mathrm{~Pa}$, heated at $373 \mathrm{~K}$ for $10 \mathrm{~h}$ and at $543 \mathrm{~K}$ for $10 \mathrm{~h}$ to remove residual moisture, purged with ultra high-purity argon gas three times, and then heated to $1073 \mathrm{~K}$ under a slow flow of argon $(\sim 10$ $\mathrm{mL} \min ^{-1}$ ) to melt the electrodes and establish electrical contact between cell components. The cell temperature was recorded using an ASTM K-type thermocouple and a thermocouple data acquisition system (NI 9211, National Instruments).

Emf measurements, using Ba-Bi alloy reference electrode at $x_{\mathrm{Ba}}=0.05$ (cell type I), were performed continuously while cooling from $1073 \mathrm{~K}$ down to $723 \mathrm{~K}$ and heating back to $1073 \mathrm{~K}$. During the thermal cycle, the cell temperature was held constant for $1.5 \mathrm{~h}$ in $25 \mathrm{~K}$ steps to reach thermal equilibrium. In the calibration experiments using the pure Ba reference electrode (cell type II), the cell temperatures were maintained below $973 \mathrm{~K}$ due to rapid degradation of the electrochemical cells above the melting temperature of barium $\left(T_{\mathrm{m}, \mathrm{Ba}}=1000 \mathrm{~K}\right)$. The emf values between the working and reference electrodes were continuously measured using a potentiostatgalvanostat (Autolab PGSTAT302N, Metrohm AG) for 180 s sequentially among Ba-Bi alloy WEs.

For cell type I, the potential difference between the two identical REs $\left(x_{\mathrm{Ba}}=0.05\right)$ was less than $2 \mathrm{mV}$ over the entire thermal cycle. For the cell type II, the potential difference between the pure barium REs drifted and diverged over time due to the high reactivity of pure $\mathrm{Ba}$. In cell type II, the emf values of Ba-Bi alloy at $x_{\mathrm{Ba}}=0.05$ were taken only when the potential difference between the pure barium REs was less than $5 \mathrm{mV}$ for better precision. 


\subsection{Characterization of Ba-Bi alloys}

Phase analysis: Phase characterization was performed by powder X-ray diffraction using an X-ray diffractometer (XRD, PANalytical Empryean) over $2 \theta$ angles $20-75^{\circ}$. The alloy samples were ground into a fine powder in an argon-filled glovebox using a mortar and pestle, and the powder samples were coated with mineral oil to minimize oxidation during measurements. The presence of mineral oil resulted in a broad amorphous background spectrum at low angles $\left(2 \theta<30^{\circ}\right)$, and the background was subtracted for phase analysis.

Thermal analysis: Differential scanning calorimetry (DSC) was performed using a thermal analyzer (Netzsch, STA 449 F3 Jupiter). About 20-50 mg of each arc-melted alloy ( $x_{\mathrm{Ba}}$ $=0.05-0.95)$ was placed on tungsten foil inside an alumina sample crucible to prevent a direct reaction between the $\mathrm{Ba}-\mathrm{Bi}$ alloy and alumina. Thermmograms were collected during heatingcooling cycles at multiple scan rates of $5-20 \mathrm{~K} \mathrm{~min}^{-1}$ under high-purity argon flow (100 mL $\left.\min ^{-1}\right)$. The phase transition temperatures were determined from the onset temperatures at various scan rates by extrapolating the onset temperatures to $0 \mathrm{~K} \mathrm{~min}^{-1}[7]$.

\section{RESULTS AND DISCUSSION}

\subsection{Emf measurements}

Figure $2 \mathrm{a}$ displays the measured emf values, $E_{\mathrm{I}}$, of Ba-Bi alloys $\left(x_{\mathrm{Ba}}=0.05,0.10,0.20\right)$ and cell temperature as a function of time, using a $\underline{\mathrm{Ba}-\mathrm{Bi}\left(x_{\mathrm{Ba}}=0.05\right)}\left|\mathrm{CaF}_{2}-\mathrm{BaF}_{2}\right| \mathrm{Ba}$ (in $\left.\mathrm{Bi}\right)$ cell. The potential difference between the two identical Ba-Bi alloys at $x_{\mathrm{Ba}}=0.05$ was less than $2 \mathrm{mV}$ during the entire measurement. Moreover, a symmetric emf profile during the heating and cooling cycles indicates that the emf measurements were reproducible, in particular at low $\mathrm{Ba}$ compositions. In general, the use of the less reactive Ba-Bi alloy RE enabled highly reproducible 
emf measurements $\left(E_{\mathrm{I}}\right)$ of $\mathrm{Ba}-\mathrm{Bi}$ alloys over a wide range of mole fractions $x_{\mathrm{Ba}}=0.10-0.80$ at $723-1073 \mathrm{~K}$.

\section{[Figure 2]}

In separate experiments, a $\underline{\mathrm{Ba}(\mathrm{s})}\left|\mathrm{CaF}_{2}-\mathrm{BaF}_{2}\right| \mathrm{Ba}-\mathrm{Bi}\left(x_{\mathrm{Ba}}=0.05\right)$ cell was employed to determine the emf values of $\mathrm{Ba}-\mathrm{Bi}$ alloy at $x_{\mathrm{Ba}}=0.05$ relative to pure barium, $E_{\mathrm{II}}$ (Figure $2 \mathrm{~b}$ ). The emf values were linear as a function of temperature according to:

$$
E_{\mathrm{II}}=1.97 \times 10^{-4} T+1.011[\mathrm{~V}]
$$

Using the linear equation (12), emf values of $\mathrm{Ba}-\mathrm{Bi}$ alloys were reported against pure barium as $E_{\text {cell }}\left(=E_{\mathrm{I}}+E_{\mathrm{II}}\right)$.

Figure 3 displays the variation of emf values with respect to temperature for $\mathrm{Ba}-\mathrm{Bi}$ alloys $x_{\mathrm{Ba}}=0.05-0.80$. In Figure $3 \mathrm{a}$, above the liquidus [liquid $=$ liquid $+\mathrm{BaBi}_{3}$, the emf increases linearly as temperature increases, and decreases monotonically as $x_{\mathrm{Ba}}$ increases. Below the liquidus, for $\mathrm{Ba}-\mathrm{Bi}$ alloys up to $x_{\mathrm{Ba}}=0.25$, emf values converge onto a single line because the activity of barium is invariant with composition in this two-phase region [liquid $+\mathrm{BaBi}_{3}$ ]. $\mathrm{Mole}$ fraction $x_{\mathrm{Ba}}=0.30$ exhibited a liquidus [liquid $=$ liquid $+\mathrm{BaBi}_{3}$ ] transition at $\sim 874 \mathrm{~K}$ and is expected to undergo solidus transition [liquid $+\mathrm{BaBi}_{3}=\mathrm{BaBi}_{3}+\mathrm{Ba}_{11} \mathrm{Bi}_{10}$ ] based on our revised phase diagram (section 3.4); however, the emf values exhibited a discontinuity at $\sim 812-836 \mathrm{~K}$ and collapsed onto the line defined as liquid $+\mathrm{BaBi}_{3}$, possibly due to the formation of nonequilibrium Bi phase during the solidification.

\section{[Figure 3]}

In Figure 3b, $x_{\mathrm{Ba}}=0.40$ exhibited two transition temperatures of liquidus [liquid $=$ liquid $+\mathrm{Ba}_{11} \mathrm{Bi}_{10}$ ] at $\sim 910 \mathrm{~K}$ and solidus [liquid $+\mathrm{Ba}_{11} \mathrm{Bi}_{10}=\mathrm{Ba}_{11} \mathrm{Bi}_{10}+\mathrm{BaBi}_{3}$ ] at $\sim 837 \mathrm{~K}$. Interestingly, mole fraction $x_{\mathrm{Ba}}=0.35$ exhibited a direct eutectic transition [liquid $=\mathrm{Ba}_{11} \mathrm{Bi}_{10}+$ 
$\left.\mathrm{BaBi}_{3}\right]$ at $\sim 843 \mathrm{~K}$. Below this solidus (or eutectic) transition temperature, emf values of these two compositions converged together within $10 \mathrm{mV}$ difference. Mole fractions $x_{\mathrm{Ba}}=0.45-0.55$ exhibited increased hysteresis during a cooling-heating cycle, up to $20 \mathrm{mV}$ difference, possibly due to the increased reactivity at high $\mathrm{Ba}$ concentrations and/or unstable physical contact between the solid-state alloy $\mathrm{WE}$ and the electrolyte. In the composition range of $x_{\mathrm{Ba}}=$ $0.45-0.55$, emf values during heating cycles exhibited a reproducible linear behavior and were therefore included in the analysis. As expected, a rapid drop in emf values was observed at high Ba mole fractions $x_{\mathrm{Ba}}=0.75-0.80$ (Figure $3 \mathrm{c}$ ) as the alloy composition approached pure $\mathrm{Ba}\left(a_{\mathrm{Ba}}\right.$ $=1)$.

From the linear fits of the data presented in Figure 3, the change in partial molar entropy of $\mathrm{Ba}$ in $\mathrm{Bi}, \Delta \bar{S}_{\mathrm{Ba}}$, was calculated from the thermodynamic relation:

$$
\Delta \bar{S}_{\mathrm{Ba}}=-\left(\frac{\partial \Delta \bar{G}_{\mathrm{Ba}}}{\partial T}\right)_{P}=2 F\left(\frac{\partial E_{\mathrm{cell}}}{\partial T}\right)_{P}
$$

and the change in partial molar enthalpy $\Delta \bar{H}_{\mathrm{Ba}}$ was obtained from the Gibbs-Helmholtz relation:

$$
\Delta \bar{H}_{\mathrm{Ba}}=-T^{2}\left(\frac{\partial\left(\Delta \bar{G}_{\mathrm{Ba}} / T\right)}{\partial T}\right)_{P}=2 F T^{2}\left(\frac{\partial\left(E_{\mathrm{cell}} / T\right)}{\partial T}\right)_{P}
$$

and the results are summarized in Table 1 . The change in partial molar entropy and enthalpy were assumed to be temperature independent over the fitted range.

\section{[Table 1]}

The activity of $\mathrm{Ba}$ was determined using the emf values and the Nernst equation at 773 $\mathrm{K}, 873 \mathrm{~K}$, and $973 \mathrm{~K}$ :

$$
\ln a_{\mathrm{Ba}}=-\frac{2 F}{R T} E_{\text {cell }} .
$$


The excess partial molar Gibbs free energy $\bar{G}_{\mathrm{Ba}}^{\mathrm{E}}$ was also calculated using

$$
\bar{G}_{\mathrm{Ba}}^{\mathrm{E}}=R T\left(\ln a_{\mathrm{Ba}}-\ln x_{\mathrm{Ba}}\right)=R T \ln \gamma_{\mathrm{Ba}}
$$

where $\gamma_{\mathrm{Ba}}$ is the activity coefficient of $\mathrm{Ba}$. The emf values, natural log of the activity, and the excess partial molar Gibbs free energy are summarized in Table 2 at each temperature. Figure 4 displays these thermodynamic properties as a function of mole fraction at $773 \mathrm{~K}$, including the liquidus composition estimated by emf measurements and intermetallic compounds determined by XRD in this study (Section 3.2).

\section{[Table 2]}

\section{[Figure 4]}

Based on equilibrium thermodynamics at a given temperature, the emf values will decrease in the single-phase region as $x_{\mathrm{Ba}}$ increases and remain constant in the two-phase regions, according to the Gibbs phase rule. This equilibrium behavior was well observed at $x_{\mathrm{Ba}}=$ $0.05-0.25$, as can be seen in Figure $4 \mathrm{a}$ where the emf values monotonically decreases as $x_{\mathrm{Ba}}$ increases in the liquid phase $\left(x_{\mathrm{Ba}} \leq 0.18\right)$ at $773 \mathrm{~K}$. In the two-phase [liquid $+\mathrm{BaBi}_{3}$ ] region $(0.18$ $<x_{\mathrm{Ba}}<0.25$ ), the emf values were nearly constant at $1.08 \mathrm{~V}$, and thus the activity values (Figure 4b). At low Ba mole fractions, a large excess partial molar Gibbs free energy was observed, as low as $-205 \mathrm{~kJ} \mathrm{~mol}^{-1}$, due to strong chemical interactions between $\mathrm{Ba}$ and Bi (Figure 4c). However, in the two-phase regions $\left[\mathrm{BaBi}_{3}+\mathrm{Ba}_{11} \mathrm{Bi}_{10}\right]$ and $\left[\mathrm{Ba}{ }_{2} \mathrm{Bi}+\mathrm{Ba}\right]$, the emf values continued to decrease as $x_{\mathrm{Ba}}$ increased (Figure 4a), deviating from equilibrium phase behavior. Such a deviation was found to originate from the presence of non-equilibrium phases within these composition ranges, confirmed by XRD analysis (see section 3.2).

Using the linear fits of emf values in the liquid phase, the emf values of selected mole fractions $x_{\mathrm{Ba}}=0.05-0.20$ were extrapolated at $1123 \mathrm{~K}$ and compared to the results by Delcet $e t$ 
al. (Table 3). In general, the difference in emf values at each composition were within 30-70 $\mathrm{mV}$, however, the emf values from this study were consistently lower compared to the values obtained by Delcet et al [3]. The difference can be attributed to, in part, the uncertainty in compositional accounting of $\mathrm{Ba}$ in their coulombic titration due to increased electronic conductivity at elevated temperatures.

\section{[Table 3]}

\subsection{Phase analysis of Ba-Bi alloys by XRD}

Powder X-ray diffraction data were collected on each arc-melted Ba-Bi alloy and the representative XRD patterns are shown in Figure 5. The measured diffraction patterns were analyzed based upon the reported crystal structures in the Ba-Bi system, listed in Table 4 [8-14]. At mole fractions $x_{\mathrm{Ba}}=0.05-0.25$, only two equilibrium phases of $\mathrm{Bi}$ and $\mathrm{BaBi}_{3}$ were observed, supporting the equilibrium behavior of the emf (or activity) trends found in this composition range (Figure 3a and Figure 4a-b). However, at mole fractions $x_{\mathrm{Ba}}>0.25$, the presence of nonequilibrium phases was apparent, including metastable $\mathrm{Bi}$ phase at $x_{\mathrm{Ba}}=0.30-0.50$ and $\mathrm{Ba}_{5} \mathrm{Bi}_{3}$ phase at $x_{\mathrm{Ba}}=0.70$. The presence of non-equilibrium phases during emf measurements will incur increased cell emf from equilibrium value depending upon the degree of meta-stability, leading to an erratic emf profile.

\section{[Table 4]}

\section{[Figure 5]}

At mole fractions $x_{\mathrm{Ba}}=0.25-0.52$, two-phase $\left[\mathrm{BaBi}_{3}+\mathrm{Ba}_{11} \mathrm{Bi}_{10}\right]$ equilibrium is expected, however, the presence of metastable Bi phase was clearly observed (Figure 5a). Mole fraction $x_{\mathrm{Ba}}=0.30$ deviated from this equilibrium behavior and was primarily comprised of $\mathrm{Bi}$ and $\mathrm{BaBi}_{3}$, which may explain why emf values converged toward [liquid $+\mathrm{BaBi}_{3}$ ] line below $\sim 812 \mathrm{~K}$ 
(Figure 3a). Interestingly, mole fractions $x_{\mathrm{Ba}}=0.45$ and 0.50 were comprised of three phases: $\mathrm{BaBi}_{3}, \mathrm{Ba}_{11} \mathrm{Bi}_{10}$, and metastable $\mathrm{Bi}$ (Figure 5a). As exemplified in Figure $4 \mathrm{a}$ at $773 \mathrm{~K}$, the inconsistent emf values over $x_{\mathrm{Ba}}=0.25-0.52$ were attributed to the presence of metastable $\mathrm{Bi}$ phase.

Similarly, at mole fractions $x_{\mathrm{Ba}}>0.67$, two-phase $\left[\mathrm{Ba}_{2} \mathrm{Bi}+\mathrm{Ba}\right]$ equilibrium is expected, and we anticipate that the emf values at fixed temperature will approach zero due to the presence of pure Ba phase, as observed in the Ca-Bi system [15]. However, the pure Ba phase was absent from mole fraction $x_{\mathrm{Ba}}=0.70$, and was identified only at a higher Ba mole fraction $x_{\mathrm{Ba}}=0.90$. Interestingly, mole fraction $x_{\mathrm{Ba}}=0.70$ was primarily composed of $\mathrm{Ba}_{2} \mathrm{Bi}$ and metastable $\mathrm{Ba}_{5} \mathrm{Bi}_{3}$ (Figure $5 \mathrm{~b}$ ). The non-equilibrium phase behavior found at $x_{\mathrm{Ba}}=0.70$ explains an exceptionally high emf value of $\sim 0.65 \mathrm{~V}$ at $773 \mathrm{~K}$ and their subsequent rapid decrease at higher Ba mole fractions (Figure 4a).

\subsection{Thermal analysis}

Phase transition temperatures of $\mathrm{Ba}-\mathrm{Bi}$ alloys $x_{\mathrm{Ba}}=0.05-0.95$ were investigated using DSC at multiple scan rates of 5-20 $\mathrm{K} \mathrm{min}^{-1}$. Representative DSC scans collected upon heating and cooling of Ba-Bi alloys at $20 \mathrm{~K} \mathrm{~min}^{-1}$ are shown in Figure 6, in which major phase transitions are designated by roman numerals (I-V). The transition temperatures were determined based on linear fits of onset temperatures as a function of scan rate and extrapolating to $0 \mathrm{~K}$ $\min ^{-1}$. The results are summarized in Table 5. In DSC measurements, the presence of metastable bismuth phase was also apparent at compositions up to $x_{\mathrm{Ba}}=0.35$. Imprecision in DSC measurements was observed for $\mathrm{Ba}-\mathrm{Bi}$ alloys, especially at high temperatures and high $\mathrm{Ba}$ compositions, and was likely due to the high reactivity of $\mathrm{Ba}-\mathrm{Bi}$ alloys at elevated temperatures and the formation of non-equilibrium phases at tested heating/cooling rates. 


\section{[Figure 6]}

\section{[Table 5]}

\subsection{Phase diagram}

Based upon phase transition temperatures from emf and DSC measurements and crystal structures from XRD analysis, a revised $\mathrm{Ba}-\mathrm{Bi}$ phase is proposed in Figure 7. The transition temperatures by emf results were obtained from the intersection of the linear fits to the emf data as a function of temperature at each mole fraction. Based on the phase behavior from the revised phase diagram, reactions were assigned to the measured transition temperatures (I-V) in Table 6 in comparison with the previous work. In general, the transition temperatures from two separate techniques of DSC and emf measurement, agreed within $10 \mathrm{~K}$ difference.

The most recent $\mathrm{Ba}-\mathrm{Bi}$ phase diagram was reported by Okamoto [16] who primarily used the differential thermal analysis data reported by Grube and Dietrich up to $x_{\mathrm{Ba}}=0.30$ [17]. In this composition range, they reported eutectic transition reaction [I: liquid $=\mathrm{Bi}+\mathrm{BaBi}_{3}$ ] at $535 \mathrm{~K}$, in good agreement with this study at $537 \mathrm{~K}$. They also reported an undefined peritectic reaction [liquid + unknown phase $\left.=\mathrm{BaBi}_{3}\right]$ at $720 \mathrm{~K}$ over $x_{\mathrm{Ba}}=0.24-0.30$, which was not identified in this study. Instead, this study suggests that the eutectic reaction [II: liquid $=\mathrm{BaBi}_{3}+\mathrm{Ba}_{11} \mathrm{Bi}_{10}$ ] at $\sim 846 \mathrm{~K}$ is the most probable transition reaction in this composition range.

Additional transition reactions and temperatures were also observed at high $\mathrm{Ba}$ mole fractions. Mole fractions $x_{\mathrm{Ba}}=0.55$ and 0.60 exhibited a transition temperature at $\sim 1007 \mathrm{~K}$ across the $\mathrm{Ba}_{4} \mathrm{Bi}_{3}\left(x_{\mathrm{Ba}}=0.57\right)$ phase, which is thought to be the allotropic transition reaction [III: $\left.\mathrm{Ba}_{4} \mathrm{Bi}_{3}(\mathrm{rt})=\mathrm{Ba}_{4} \mathrm{Bi}_{3}(\mathrm{ht})\right]$. The eutectic transition reaction [IV: liquid $\left.=\mathrm{Ba}_{2} \mathrm{Bi}+\mathrm{Ba}(\mathrm{ht})\right]$ was observed from both DSC and emf measurements at $\sim 864-873 \mathrm{~K}$, and the allotropic reaction [V: $\mathrm{Ba}(\mathrm{rt})=\mathrm{Ba}(\mathrm{ht})]$ at $796 \mathrm{~K}$ from DSC measurement. 
Not included in this phase diagram are the crystalline phases of $\mathrm{Ba}_{16} \mathrm{Ba}_{11}$ and $\mathrm{Ba}_{2} \mathrm{Bi}_{3}$. Ponou et al. reported that a single crystal $\mathrm{Ba}_{2} \mathrm{Bi}_{3}$ phase was obtained through a reaction at 1123 $\mathrm{K}$ in a sealed $\mathrm{Nb}$ crucible, followed by annealing at $773 \mathrm{~K}$ for $48 \mathrm{~h}$ with slow cooling rate $1 \mathrm{~K}$ $\min ^{-1}[18]$; Leon-Escamilla et al. obtained $\mathrm{Ba}_{16} \mathrm{Bi}_{11}$ through a reaction at $1273 \mathrm{~K}$ in a Ta crucible, followed by annealing at 1098-1173 K for 8-24 h [19]. However, these two phases were not observed in this study, possibly due to relatively high heating-cooling rates $\left(>5 \mathrm{~K} \mathrm{~min}^{-1}\right)$ in DSC measurements and insufficient time $(1.5 \mathrm{~h})$ for reaching equilibrium in emf measurements.

\section{[Table 6]}

\section{[Figure 7]}

\section{CONCLUSIONS}

Thermodynamic properties of binary Ba-Bi alloys were determined by emf, DSC, and XRD techniques. These measurements determined the activity, partial molar entropy, enthalpy, transition temperatures, as well as transition reactions of $\mathrm{Ba}-\mathrm{Bi}$ alloys, resulting in a revised $\mathrm{Ba}-$ Bi phase diagram. Near equilibrium phase behavior was observed at $x_{\mathrm{Ba}}=0.05-0.25$, resulting in reliable emf measurements while erratic emf behavior was observed at higher Ba mole fractions due to the formation of metastable phases.

The revised phase diagram suggests that liquid-state solubility of $\mathrm{Ba}$ in $\mathrm{Bi}$ is $\sim 18 \mathrm{~mol} \%$ at $773 \mathrm{~K}$ and increases up to $\sim 40 \mathrm{~mol} \%$ at $923 \mathrm{~K}$. The activity values of Ba were as low as $\sim 10^{-15}$ at $x_{\mathrm{Ba}}=0.05$ and $773 \mathrm{~K}$, implying strong chemical interactions between $\mathrm{Ba}$ and $\mathrm{Bi}$. Based upon such a low thermodynamic activity and high liquid-state solubility, liquid Bi metal shows promise as an electrode material in separating $\mathrm{Ba}$ ions from molten salt electrolytes (e.g., LiCl$\mathrm{KCl}-\mathrm{BaCl}_{2}$ ). 


\section{Acknowledgements:}

The financial support of the US Department of Energy, Office of Nuclear Energy's Nuclear Energy University Programs (Award No. DE-NE0008425) is gratefully acknowledged. The authors would like to thank Tobias Frueh for his advice in synthesizing the solid electrolyte using powder processing techniques, Michael Brova for helpful discussion with thermal analysis, and Jason Munro for his help in processing a large amount of data. 


\section{References:}

[1] H. Kim, N. Smith, K. Kumar, T. Lichtenstein, Electrochemical Separation of Barium into Liquid Bismuth by Controlling Deposition Potentials, Electrochim. Acta. 220 (2016) 237244. doi:10.1016/j.electacta.2016.10.083.

[2] H. Kim, D.A. Boysen, T. Ouchi, D.R. Sadoway, Calcium-bismuth electrodes for largescale energy storage (liquid metal batteries), J. Power Sources. 241 (2013) 239-248. doi:10.1016/j.jpowsour.2013.04.052.

[3] J. Delcet, A. Delgado-Brune, J.J. Egan, Coulometric Titrations Using CaF2 and BaF2 Solid Electrolytes to Study Alloy Phases, in: Y.A. Chang, J.F. Smith (Eds.), Symp. Calc. Phase Diagrams Thermocehmistry Alloy Phases, Metallurgical Society of AIME, Milwaukee, 1979: pp. 275-287.

[4] H. Schäfer, A. Niklas, Sudwestdeutsche Dozententagung in FreiburglBr., Angew. Chemie. 64 (1952) 611.

[5] HSC Chemistry 5.1, F. Outokumpu Research Oy, Finland, 2002.

[6] R.W. Ure, Ionic Conductivity of Calcium Fluoride Crystals, J. Chem. Phys. 26 (1957) 1363-1373. doi:10.1063/1.1743547.

[7] E.B. Ferreira, M.L. Lima, E.D. Zanotto, DSC method for determining the liquidus temperature of glass-forming systems, J. Am. Ceram. Soc. 93 (2010) 3757-3763. doi:10.1111/j.1551-2916.2010.03976.x.

[8] M.E. Straumanis, The precision determination of lattice constants by the powder and rotating crystal methods and applications, J. Appl. Phys. 20 (1949) 726-734. 
doi:10.1063/1.1698520.

[9] N.N. Zhuravlev, V.R. Adamyan Melik, Study of the crystal structure of the superconducting compounds SrBi3 and BaBi3, Sov. Phys. Crystallogr. 6 (1961) 99-100.

[10] G. Derrien, M. Tillard-Charbonnel, A. Manteghetti, L. Monconduit, C. Belin, Synthesis and Crystal Structure of M11X10 Compounds, M=Sr, Ba and X=Bi, Sb. Electronic Requirements and Chemical Bonding, J. Solid State Chem. 164 (2002) 169-175. doi:10.1006/jssc.2001.9470.

[11] B. Li, A.V. Mudring, J.D. Corbett, Valence Compounds versus Metals. Synthesis, Characterization, and Electronic Structures of Cubic Ae4Pn3 Phases in the Systems Ae = Ca, Sr, Ba, Eu; Pn = As, Sb, Bi, Inorg. Chem. 42 (2003) 6940-6945. doi:10.1021/ic0301472.

[12] B. Eisenmann, K. Deller, Zur Kenntnis der Erdalkaliantimonide und -wismutide Sr2Bi, Ba2Sb, Sr5Bi3, Ba5Sb3 und Ba5Bi3, Zeitschrift Fur Naturforsch. - Sect. B J. Chem. Sci. 30 (1975) 66-72. doi:10.1515/znb-1975-1-218.

[13] M. Martinez-Ripoll, A. Haase, G. Brauer, The crystal structure of Ba2Bi, Acta Crystallogr. Sect. B Struct. Crystallogr. Cryst. Chem. 30 (1974) 2003-2004. doi:10.1107/S0365110X55000716.

[14] J. Evers, G. Oehlinger, B. Sendlinger, A. Weiss, M. Schmidt, P. Schramel, Lattice parameter of a high purity barium wire extruded in ultrahigh vacuum, J. Alloys Compd. 182 (1992) 175-187. doi:10.1016/0925-8388(92)90586-X.

[15] H. Kim, D.A. Boysen, D.J. Bradwell, B. Chung, K. Jiang, A.A. Tomaszowska, K. Wang, 


\section{TABLES and FIGURES}

Table 1. Change in partial molar entropy and enthalpy of barium calculated from linear fits to the emf data versus temperature for $x_{\mathrm{Ba}}=0.05-0.80$, where the slopes and intercepts are $\partial E_{\text {cell }} / \partial T$ and $T^{2}\left(\partial\left(E_{\text {cell }} / T\right) / \partial T\right)$, respectively. The $a d j-R^{2}$ value for each linear fit is reported.

\begin{tabular}{lllllll}
\hline$x_{\mathrm{Ba}}$ & $T(\mathrm{~K})$ & $\begin{array}{l}\partial E_{\text {cell }} / \partial T \\
\left(\mu \mathrm{V} \mathrm{K} \mathrm{K}^{-1}\right)\end{array}$ & $\begin{array}{l}T^{2}\left(\partial\left(E_{\mathrm{cell}} / T\right) / \partial T\right) \\
(\mathrm{mV})\end{array}$ & $\begin{array}{l}\Delta \bar{S}_{\mathrm{Ba}} \\
\left(\mathrm{J} \mathrm{mol}^{-1} \mathrm{~K}^{-1}\right)\end{array}$ & $\begin{array}{l}\Delta \bar{H}_{\mathrm{Ba}} \\
\left(\mathrm{kJ} \mathrm{mol}^{-1}\right)\end{array}$ & $a^{2}-R^{2}$ \\
\hline 0.05 & $707-938$ & $197 \pm 6$ & $1011 \pm 5$ & 38.0 & -195.1 & 0.96 \\
0.10 & $704-1048$ & $137 \pm 1$ & $1031 \pm 1$ & 26.4 & -199.0 & 0.99 \\
0.15 & $728-1048$ & $125 \pm 2$ & $1005 \pm 2$ & 24.1 & -193.9 & 0.99 \\
0.20 & $809-1048$ & $94 \pm 7$ & $984 \pm 6$ & 18.1 & -189.9 & 0.90 \\
0.25 & $881-1048$ & $73.4 \pm 5$ & $961 \pm 5$ & 14.2 & -185.4 & 0.93 \\
& $704-881$ & $-480 \pm 14$ & $1448 \pm 13$ & -92.6 & -279.4 & 0.98 \\
0.30 & $864-1048$ & $54.7 \pm 7$ & $958 \pm 7$ & 105.6 & -184.8 & 0.80 \\
& $704-864$ & $-614 \pm 43$ & $1545 \pm 34$ & -118.5 & -298.1 & 0.93 \\
0.35 & $875-1033$ & $51.8 \pm 7$ & $932 \pm 6$ & 10.0 & -179.8 & 0.80 \\
& $691-875$ & $19.8 \pm 1$ & $961 \pm 6$ & 3.8 & -185.4 & 0.85 \\
0.40 & $913-1033$ & $44.6 \pm 11$ & $896 \pm 10$ & 8.6 & -172.9 & 0.81 \\
& $812-913$ & $-501 \pm 71$ & $1398 \pm 61$ & -96.7 & -270.0 & 0.91 \\
& $691-812$ & $-29.4 \pm 7$ & $1006 \pm 8$ & -5.7 & -194.1 & 0.84 \\
0.45 & $715-961$ & $-215 \pm 9$ & $1085 \pm 7$ & -41.5 & -209.4 & 0.98 \\
0.50 & $715-961$ & $-271 \pm 17$ & $1097 \pm 14$ & -52.3 & -211.7 & 0.97 \\
0.55 & $740-1041$ & $-201 \pm 17$ & $967 \pm 15$ & -38.8 & -186.6 & 0.92 \\
0.70 & $770-957$ & $6.9 \pm 0.6$ & $645 \pm 12$ & 1.3 & -124.5 & 0.84 \\
0.75 & $866-1030$ & $-542 \pm 40$ & $683 \pm 38$ & -104.6 & -131.8 & 0.96 \\
& $697-866$ & $-2900 \pm 155$ & $2716 \pm 121$ & -559.6 & -524.1 & 0.98 \\
0.80 & $862-1034$ & $222 \pm 15$ & $-206 \pm 14$ & 42.8 & -39.8 & 0.97 \\
& $717-862$ & $-530 \pm 49$ & $444 \pm 38$ & -102.3 & -85.7 & 0.96 \\
\hline
\end{tabular}


Table 2. Measured emf values, the natural $\log$ of activity of $\mathrm{Ba}$, and the excess partial molar Gibbs free energy of Ba-Bi alloys over $x_{\mathrm{Ba}}=0.05-0.80$ at $773 \mathrm{~K}, 873 \mathrm{~K}$, and $973 \mathrm{~K}$.

\begin{tabular}{|c|c|c|c|c|c|c|c|c|c|}
\hline \multirow[t]{2}{*}{$x_{\mathrm{Ba}}$} & \multicolumn{3}{|l|}{$E(\mathrm{~V})$} & \multicolumn{3}{|l|}{$\ln a_{\mathrm{Ba}}$} & \multicolumn{3}{|c|}{$\bar{G}_{\mathrm{Ba}}^{\mathrm{E}}\left(\mathrm{kJ} \mathrm{mol}^{-1}\right)$} \\
\hline & $773 \mathrm{~K}$ & $873 \mathrm{~K}$ & $973 \mathrm{~K}$ & $773 \mathrm{~K}$ & $873 \mathrm{~K}$ & $973 \mathrm{~K}$ & $773 \mathrm{~K}$ & $873 \mathrm{~K}$ & $973 \mathrm{~K}$ \\
\hline 0.05 & 1.164 & 1.183 & 1.203 & -35.0 & -31.5 & -28.7 & -205 & -206 & -208 \\
\hline 0.10 & 1.137 & 1.150 & 1.164 & -34.1 & -30.6 & -27.8 & -205 & -205 & -206 \\
\hline 0.15 & 1.101 & 1.114 & 1.127 & -33.0 & -29.6 & -26.9 & -200 & -201 & -202 \\
\hline 0.20 & 1.075 & 1.066 & 1.076 & -32.2 & -28.3 & -25.7 & -197 & -194 & -194 \\
\hline 0.25 & 1.075 & 1.027 & 1.032 & -32.2 & -27.3 & -24.6 & -198 & -188 & -188 \\
\hline 0.30 & 1.069 & 1.006 & 1.011 & -32.0 & -26.7 & -24.1 & -198 & -185 & -185 \\
\hline 0.35 & 0.986 & 0.980 & 0.982 & -29.6 & -26.1 & -23.4 & -184 & -181 & -181 \\
\hline 0.40 & 0.986 & 0.960 & 0.939 & -29.6 & -25.5 & -22.4 & -184 & -178 & -173 \\
\hline 0.45 & 0.924 & 0.899 & 0.861 & -27.7 & -23.9 & -20.5 & -173 & -167 & -159 \\
\hline 0.50 & 0.877 & 0.855 & 0.847 & -26.3 & -22.7 & -20.2 & -164 & -160 & -157 \\
\hline 0.55 & 0.816 & 0.795 & 0.773 & -24.5 & -21.1 & -18.4 & -154 & -149 & -144 \\
\hline 0.70 & 0.647 & 0.651 & 0.648 & -19.4 & -17.3 & -15.5 & -122 & -123 & -122 \\
\hline 0.75 & 0.474 & 0.209 & 0.155 & -14.2 & -5.6 & -3.7 & -90 & -38 & -27 \\
\hline 0.80 & 0.034 & 0.000 & 0.010 & -1.02 & 0.0 & -0.24 & -5 & 1 & 0 \\
\hline
\end{tabular}


Table 3. The estimated emf, partial molar Gibbs free energy, and activity values of $\mathrm{Ba}$ in $\mathrm{Bi}$ at $1123 \mathrm{~K}$ based on the extrapolation of the linear fit, compared to the results by Delcet $e t$ al. [3].

\begin{tabular}{llllllll}
\hline$x_{\mathrm{Ba}}$ & \multicolumn{3}{c}{ This study } & & \multicolumn{3}{c}{ Delcet et al. } \\
\cline { 2 - 3 } & $E_{\text {cell }}(\mathrm{V})$ & $\Delta \bar{G}_{\mathrm{Ba}}\left(\mathrm{kJ} \mathrm{mol}^{-1}\right)$ & $a_{\mathrm{Ba}}$ & & $E_{\text {cell }}(\mathrm{V})$ & $\Delta \bar{G}_{\mathrm{Ba}}\left(\mathrm{kJ} \mathrm{mol}^{-1}\right)$ & $a_{\mathrm{Ba}}$ \\
\hline 0.05 & 1.23 & -237.8 & $8.7 \times 10^{-12}$ & & 1.30 & -250.0 & $2.4 \times 10^{-12}$ \\
0.10 & 1.18 & -228.6 & $2.3 \times 10^{-11}$ & & 1.24 & -238.9 & $7.7 \times 10^{-12}$ \\
0.15 & 1.15 & -221.0 & $5.3 \times 10^{-11}$ & & 1.18 & -227.9 & $2.5 \times 10^{-11}$ \\
0.20 & 1.09 & -210.3 & $1.7 \times 10^{-10}$ & & 1.12 & -215.6 & $9.4 \times 10^{-11}$ \\
\hline
\end{tabular}

Table 4. Summary of the crystal structures in Ba-Bi system reported in this work [8-14].

\begin{tabular}{|c|c|c|c|c|c|c|}
\hline Phase & $x_{\mathrm{Ba}}$ & $\begin{array}{l}\text { Density } \\
\left(\mathrm{g} \mathrm{cm}^{-3}\right)\end{array}$ & $\begin{array}{c}\text { Space group } \\
\text { (Pearson symbol) }\end{array}$ & $\begin{array}{l}\text { Lattice } \mathrm{F} \\
(\mathrm{nm})\end{array}$ & $\begin{array}{l}\text { ameters } \\
\left({ }^{\circ}\right)\end{array}$ & Ref. \\
\hline $\mathrm{Bi}$ & 0.00 & 9.81 & $\begin{array}{l}R \overline{3} m \\
(h R 6)\end{array}$ & $\begin{array}{l}a=0.455 \\
b=0.455 \\
c=1.19\end{array}$ & $\begin{array}{l}\alpha=90 \\
\beta=90 \\
\gamma=120\end{array}$ & [8] \\
\hline $\mathrm{BaBi}_{3}$ & 0.25 & 9.14 & $\begin{array}{l}P 4 \bar{m} m m \\
\quad(\mathrm{tP} 4)\end{array}$ & $\begin{array}{l}a=0.519 \\
b=0.519 \\
c=0.516\end{array}$ & $\begin{array}{l}\alpha=90 \\
\beta=90 \\
\gamma=90\end{array}$ & [9] \\
\hline $\mathrm{Ba}_{11} \mathrm{Bi}_{10}$ & 0.52 & 7.06 & $\begin{array}{l}I 4 \bar{m} m m \\
(\mathrm{t} 184)\end{array}$ & $\begin{array}{l}a=1.323 \\
b=1.323 \\
c=1.936\end{array}$ & $\begin{array}{l}\alpha=90 \\
\beta=90 \\
\gamma=90\end{array}$ & [10] \\
\hline $\mathrm{Ba}_{4} \mathrm{Bi}_{3}$ & 0.57 & 6.65 & $\begin{array}{l}I \overline{4} 3 d \\
(\mathrm{cl} 28)\end{array}$ & $\begin{array}{l}a=1.055 \\
b=1.055 \\
c=1.055\end{array}$ & $\begin{array}{l}\alpha=90 \\
\beta=90 \\
\gamma=90\end{array}$ & [11] \\
\hline $\mathrm{Ba}_{5} \mathrm{Bi}_{3}$ & 0.63 & 6.30 & $\begin{array}{c}P 6_{3} \bar{m} c m \\
\text { (hP16) }\end{array}$ & $\begin{array}{l}a=1.013 \\
b=1.013 \\
c=0.779\end{array}$ & $\begin{array}{l}\alpha=90 \\
\beta=90 \\
\gamma=120\end{array}$ & [12] \\
\hline $\mathrm{Ba}_{2} \mathrm{Bi}$ & 0.66 & 6.20 & $\begin{array}{l}I 4 \bar{m} m m \\
(\mathrm{tl} 12)\end{array}$ & $\begin{array}{l}a=0.526 \\
b=0.526 \\
c=1.870\end{array}$ & $\begin{array}{l}\alpha=90 \\
\beta=90 \\
\gamma=90\end{array}$ & [13] \\
\hline $\mathrm{Ba}$ & 1.00 & 3.59 & $\begin{array}{c}\operatorname{Im} \overline{3} m \\
(\mathrm{cl} 2)\end{array}$ & $\begin{array}{l}a=0.503 \\
b=0.503 \\
c=0.503\end{array}$ & $\begin{array}{l}\alpha=90 \\
\beta=90 \\
\gamma=90\end{array}$ & [14] \\
\hline
\end{tabular}


Table 5. Summary of transition temperatures $T_{\text {trs }}(\mathrm{K})$ determined by differential scanning calorimetry over multiple scan rates and the standard error in the parenthesis.

\begin{tabular}{lllllll}
\hline & $T_{\text {trs }}(\mathrm{K})$ & & & & & \\
$x_{\mathrm{Ba}}$ & I & II & III & IV & V & Liquidus \\
\hline 0.05 & $538(1)$ & - & - & - & - & - \\
0.10 & $547(4)$ & - & - & - & - & - \\
0.15 & $538(1)$ & - & - & - & - & - \\
0.20 & $538(1)$ & - & - & - & - & $813(9)$ \\
0.25 & $537(1)$ & - & - & - & - & $863(14)$ \\
0.30 & $545(3)$ & - & - & - & - & - \\
0.35 & $538(2)$ & $853(3)$ & - & - & - & - \\
0.40 & - & $846(4)$ & - & - & - & $926(8)$ \\
0.45 & - & $847(1)$ & - & - & - & - \\
0.50 & - & $844(2)$ & - & - & - & $1043(3)$ \\
0.55 & - & - & $1010(8)$ & - & - & $1067(1)$ \\
0.60 & - & - & $1004(9)$ & - & - & $1056(3)$ \\
0.70 & - & - & - & - & - & $972(3)$ \\
0.75 & - & - & - & - & - & $969(4)$ \\
0.80 & - & - & - & - & $797(1)$ & $958(15)$ \\
0.85 & - & - & - & - & - & $935(11)$ \\
0.90 & - & - & - & - & $796(4)$ & $904(24)$ \\
0.95 & - & - & - & $873(9)$ & $796(1)$ & - \\
\hline
\end{tabular}

Table 6. Reactions assigned to the transition temperatures determined by DSC in Table 6 and emf measurements, in comparison to the previous report by Okamoto [16].

\begin{tabular}{llllll}
\hline Transition & Reaction & $\begin{array}{l}T_{\text {trr }}(\mathrm{K}) \\
\mathrm{DSC}\end{array}$ & Emf & Okamoto & Type \\
\hline $\mathrm{I}$ & liquid $=\mathrm{Bi}+\mathrm{BaBi}_{3}$ & $537(5)$ & - & 535 & Eutectic \\
$*$ & liquid $+?=\mathrm{BaBi}_{3}$ & - & - & 720 & Peritectic \\
II & liquid $=\mathrm{BaBi}_{3}+\mathrm{Ba}_{11} \mathrm{Bi}_{10}$ & $846(4)$ & $843(6)$ & - & Eutectic \\
III & $\mathrm{Ba}_{4} \mathrm{Bi}_{3}(\mathrm{rt})=\mathrm{Ba}_{4} \mathrm{Bi}_{3}(\mathrm{ht})$ & $1007(9)$ & - & - & Allotropic \\
IV & liquid $=\mathrm{Ba} \mathrm{Bi}_{2}+\mathrm{Ba}(\mathrm{ht})$ & $873(9)$ & $864(2)$ & - & Eutectic \\
V & $\mathrm{Ba}(\mathrm{rt})=\mathrm{Ba}(\mathrm{ht})$ & $796(4)$ & - & - & Allotropic \\
$*:$ undefined phase transition reaction reported by Okamoto at 720 K.
\end{tabular}




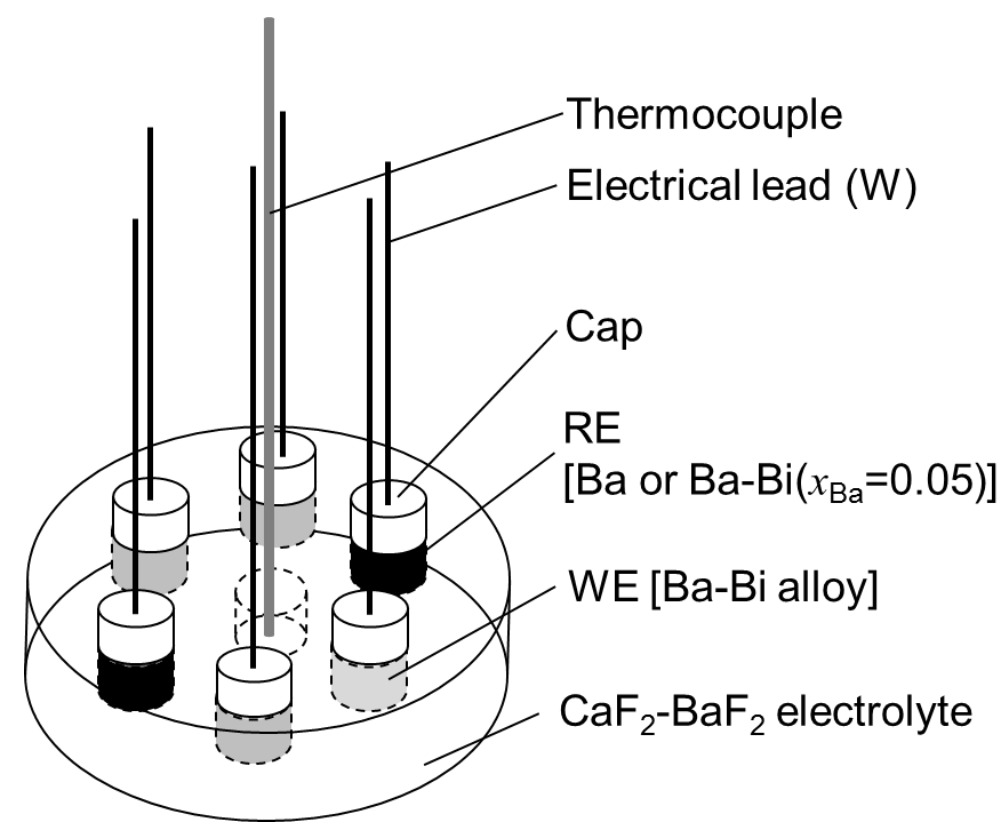

Figure 1. Illustration of the $\underline{\mathrm{Ba}-\mathrm{Bi}\left(x_{\mathrm{Ba}}=0.05\right)}\left|\mathrm{CaF}_{2}-\mathrm{BaF}_{2}\right| \mathrm{Ba}$ (in $\left.\mathrm{Bi}\right)$ or $\underline{\mathrm{Ba}(\mathrm{s})}\left|\mathrm{CaF}_{2}-\mathrm{BaF}_{2}\right| \mathrm{Ba}-\mathrm{Bi}\left(x_{\mathrm{Ba}}\right.$ $=0.05)$ cells used for emf measurements, with the positions of thermocouple, working electrodes (WEs), and reference electrodes (REs) indicated. 


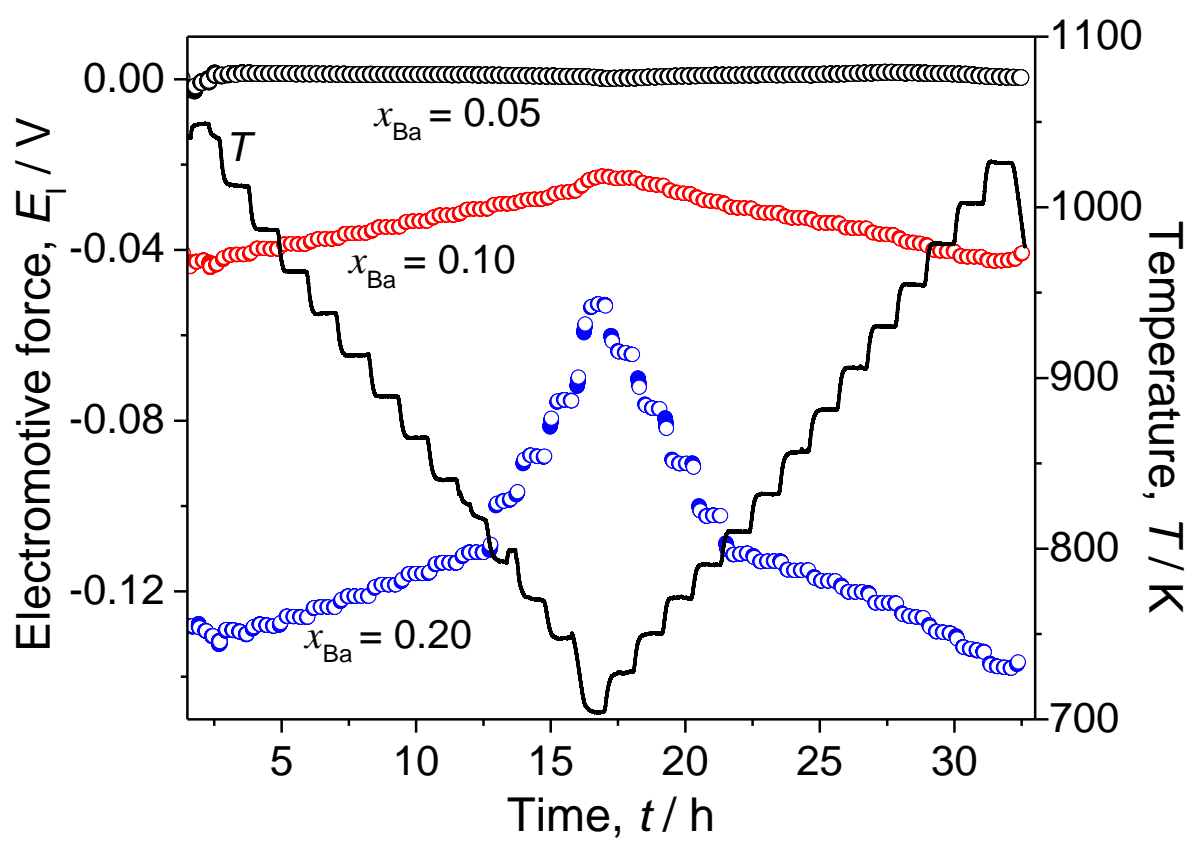

Figure 2a.

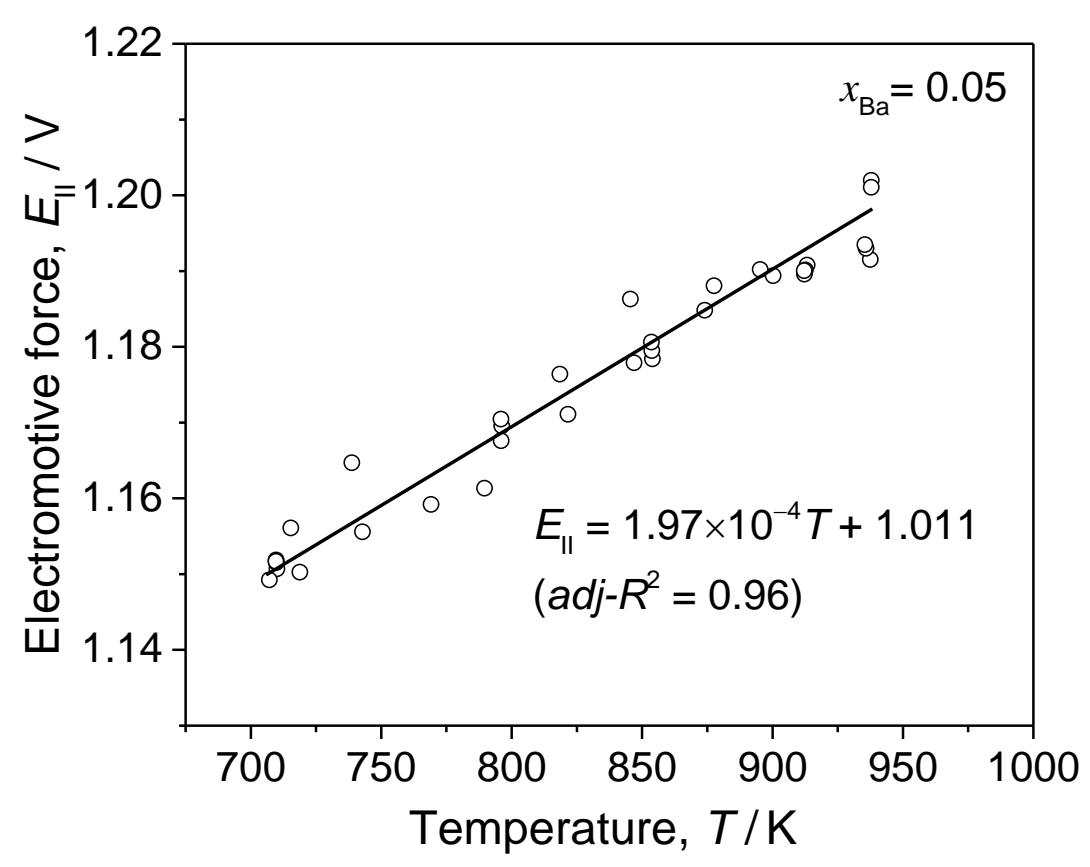

Figure 2b.

Figure 2. (a) The measured emf values $\left(E_{\mathrm{I}}\right)$ and temperature as a function of time upon cooling and reheating a $\underline{\mathrm{Ba}-\mathrm{Bi}\left(x_{\mathrm{Ba}}=0.05\right)}\left|\mathrm{CaF}_{2}-\mathrm{BaF}_{2}\right| \mathrm{Ba}$ (in $\left.\mathrm{Bi}\right)$ cell with $\mathrm{Ba}-\mathrm{Bi}$ alloys $x_{\mathrm{Ba}}=0.05,0.10$, and 0.20 and (b) the measured emf values $\left(E_{\mathrm{II}}\right)$ using a $\underline{\mathrm{Ba}(\mathrm{s})}\left|\mathrm{CaF}_{2}-\mathrm{BaF}_{2}(\mathrm{~s})\right| \mathrm{Ba}-\mathrm{Bi}\left(x_{\mathrm{Ba}}=0.05\right)$ cell. 


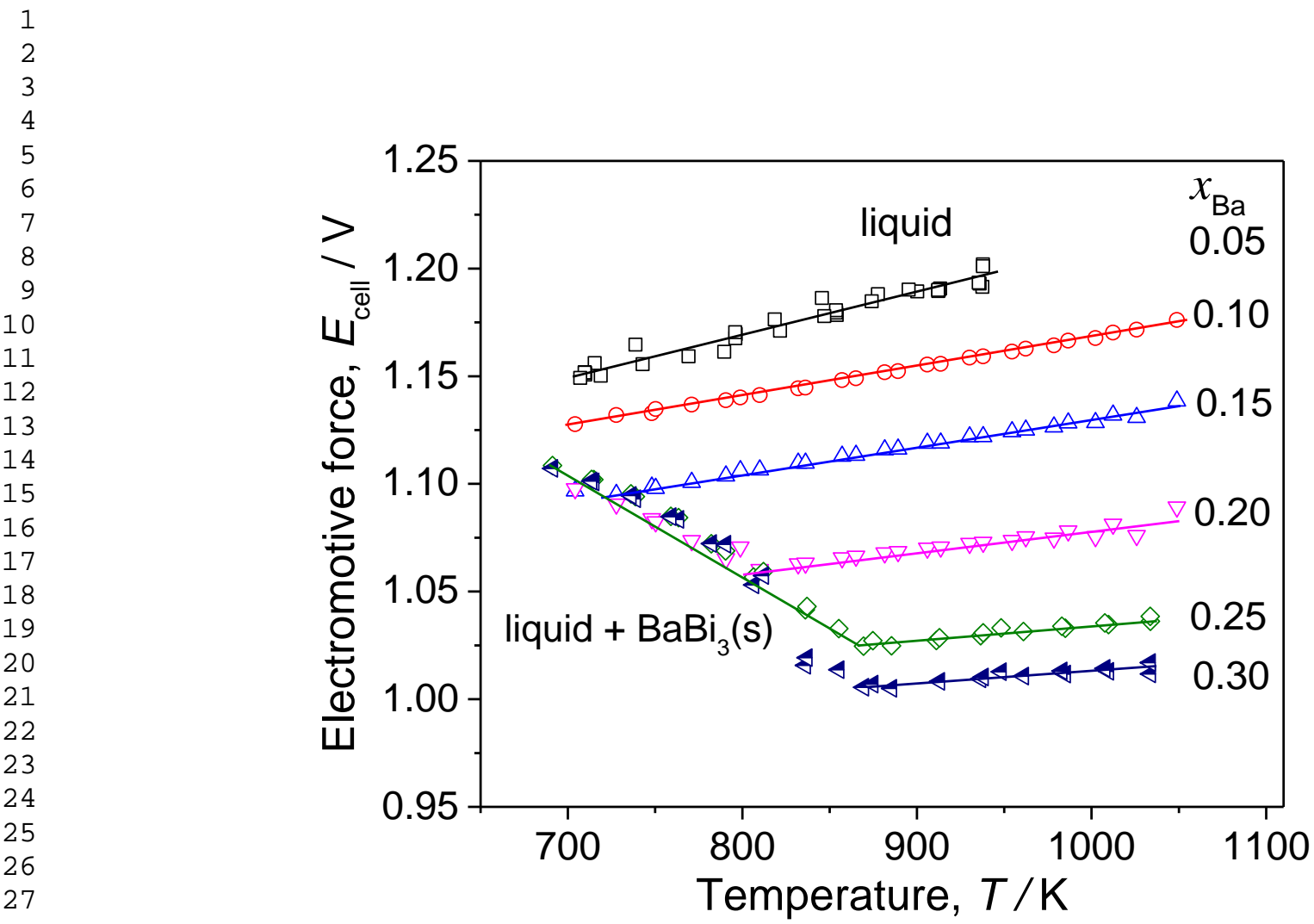

Figure 3a.

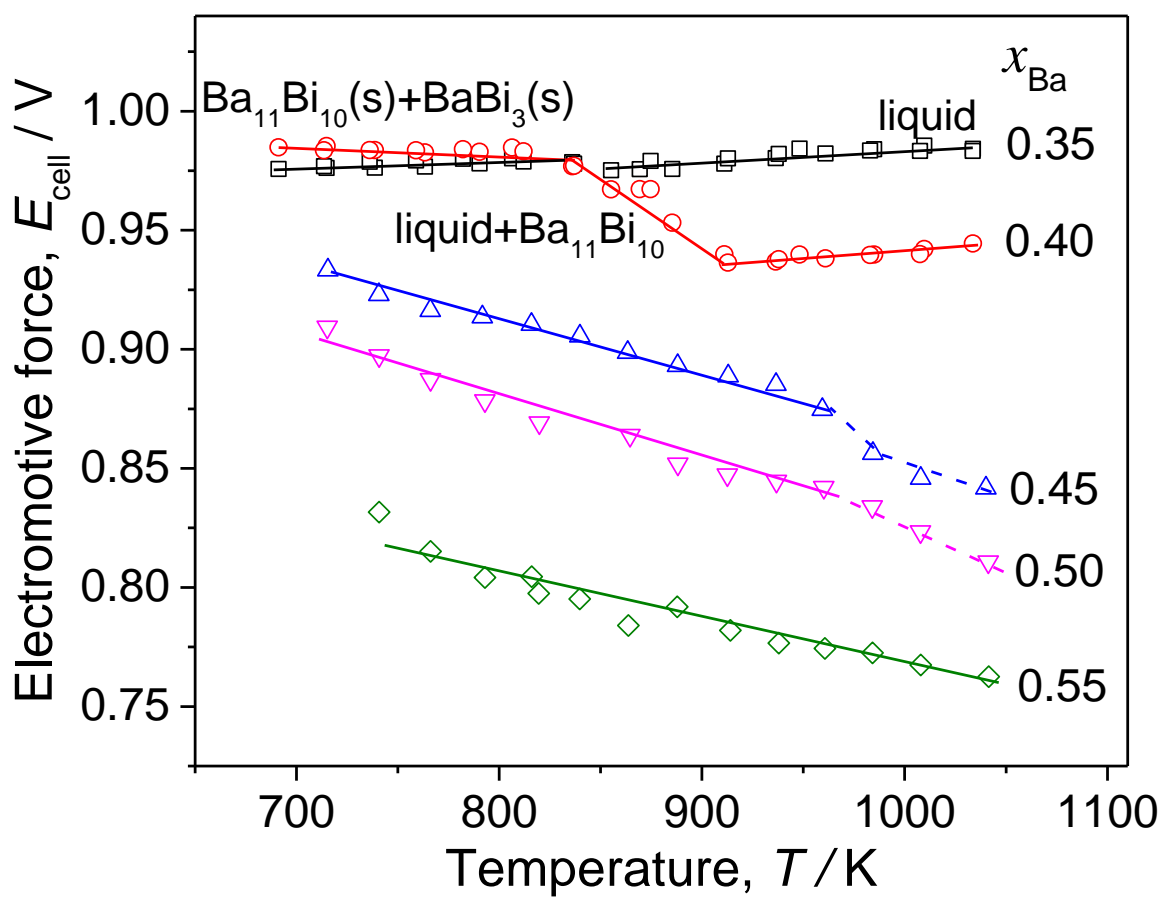

Figure 3b. 


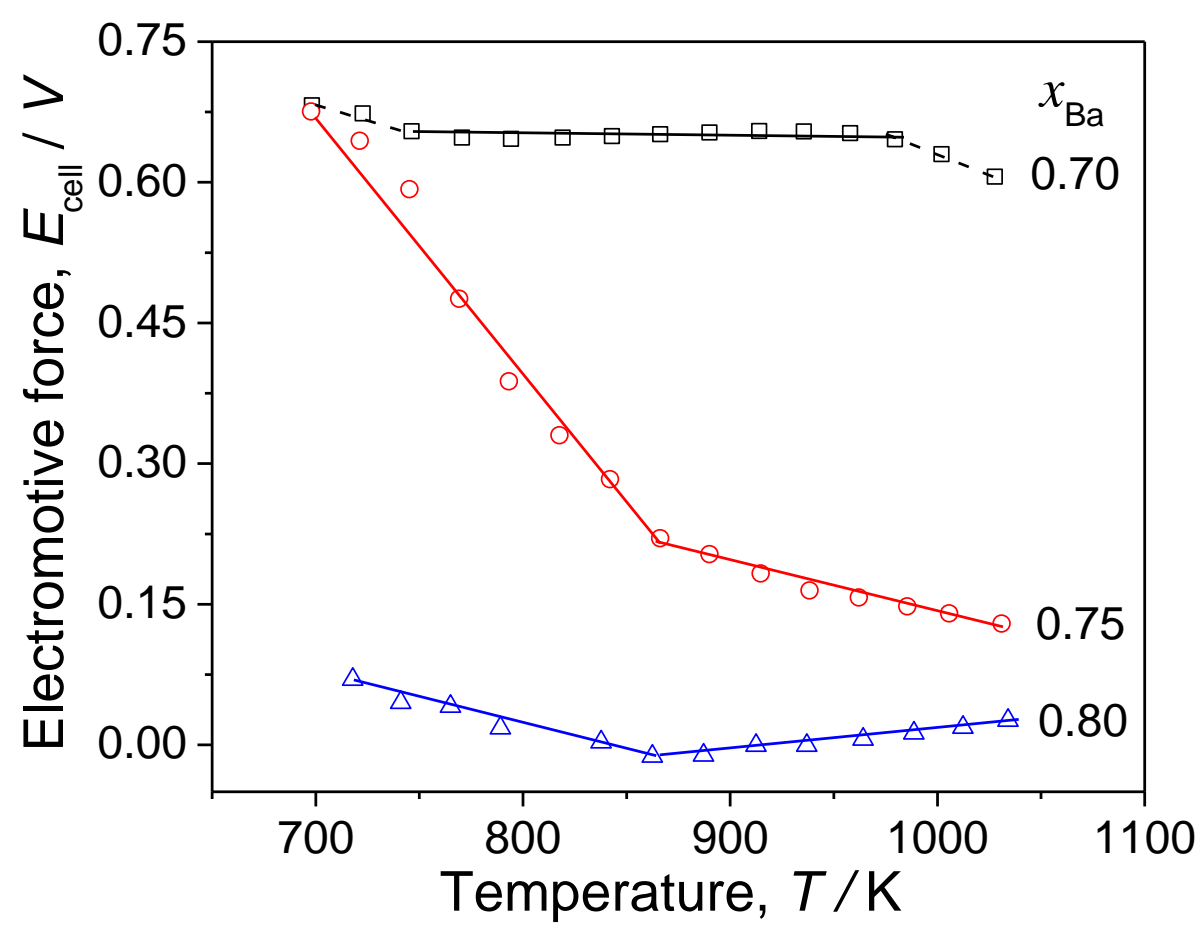

Figure 3c.

Figure 3. The emf as a function of temperature for (a) $x_{\mathrm{Ba}}=0.05$ to 0.30 , (b) $x_{\mathrm{Ba}}=0.35$ to 0.55 and (c) $x_{\mathrm{Ba}}=0.70$ to 0.80 , where solid lines represent linear fits and dashed lines are a visual guide. 


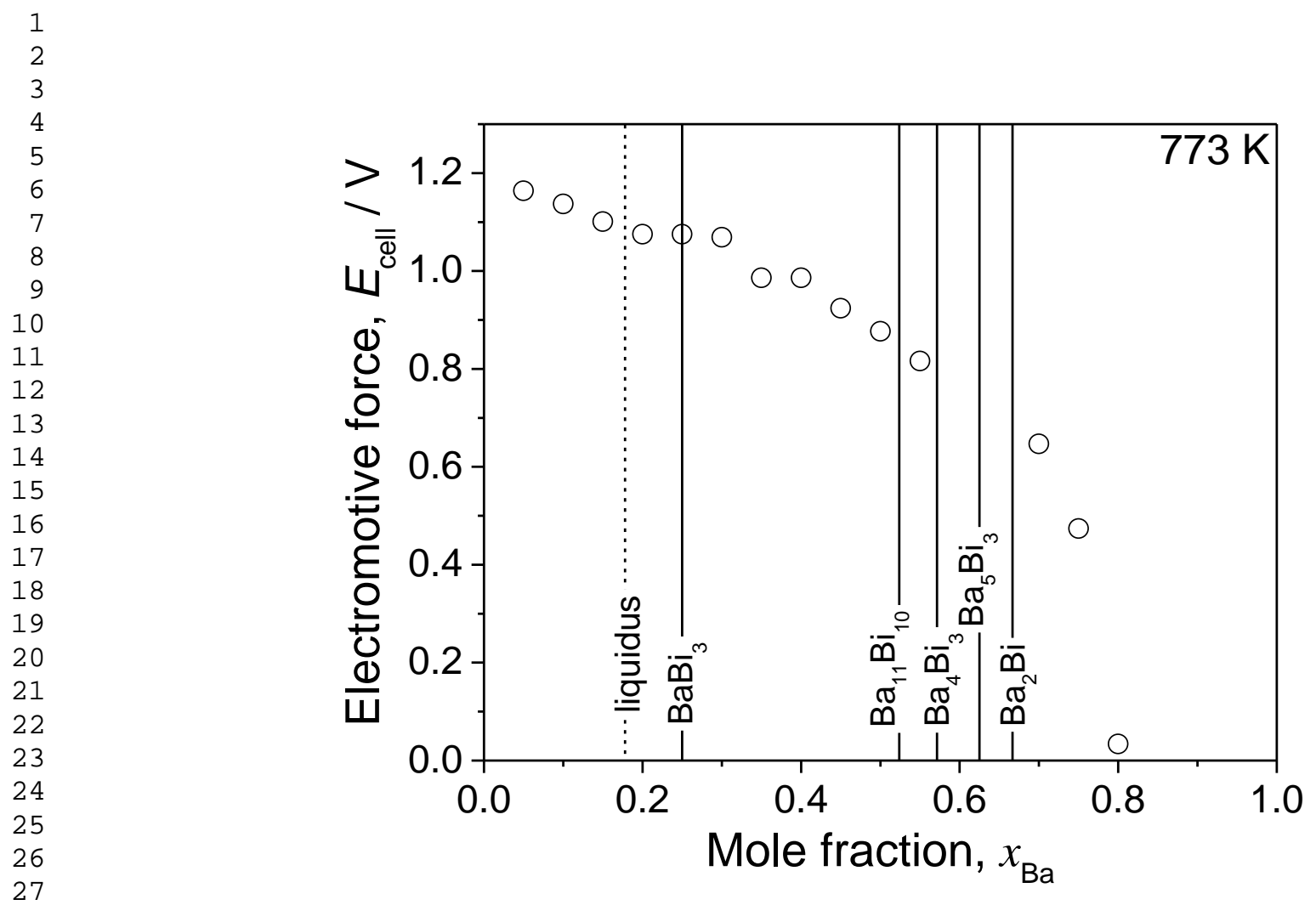

Figure $4 a$.

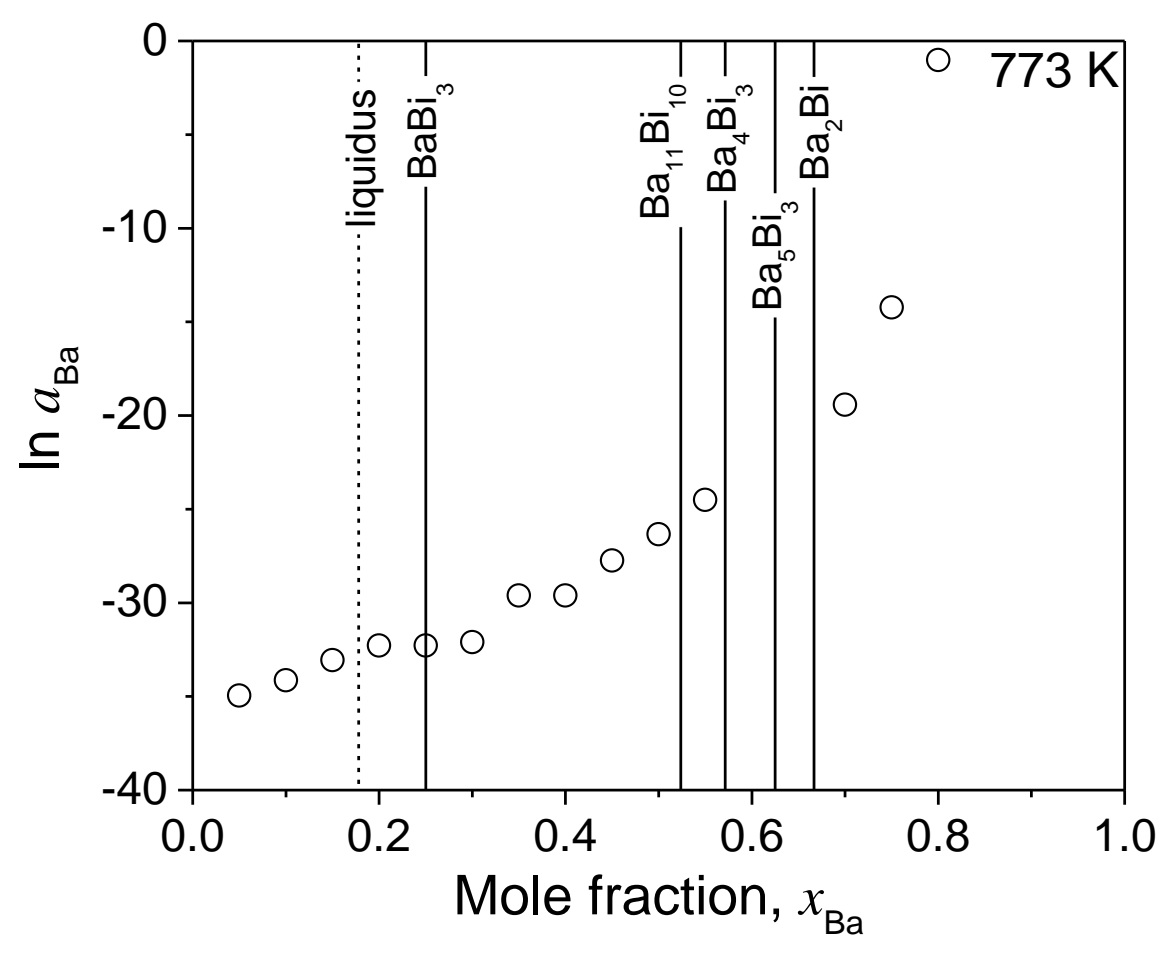

Figure $4 b$. 


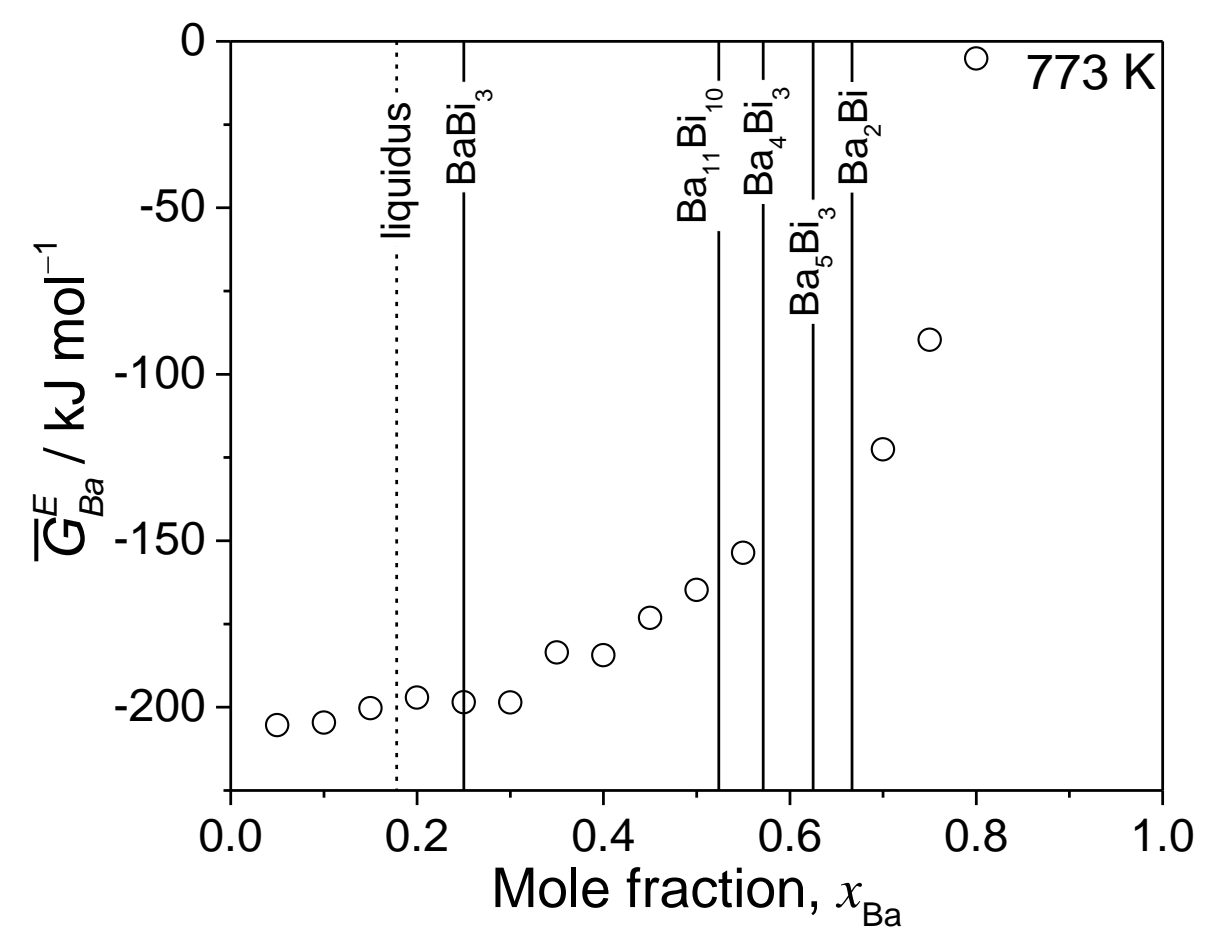

Figure 4c.

Figure 4. Plots of the (a) measured emf values $\left(E_{\text {cell }}\right)$, (b) the natural $\log$ of the activity of Ba (ln $a_{\mathrm{Ba}}$, and (c) the calculated excess partial molar Gibbs free energy of $\mathrm{Ba}$ as a function of mole fraction at $773 \mathrm{~K}$. 


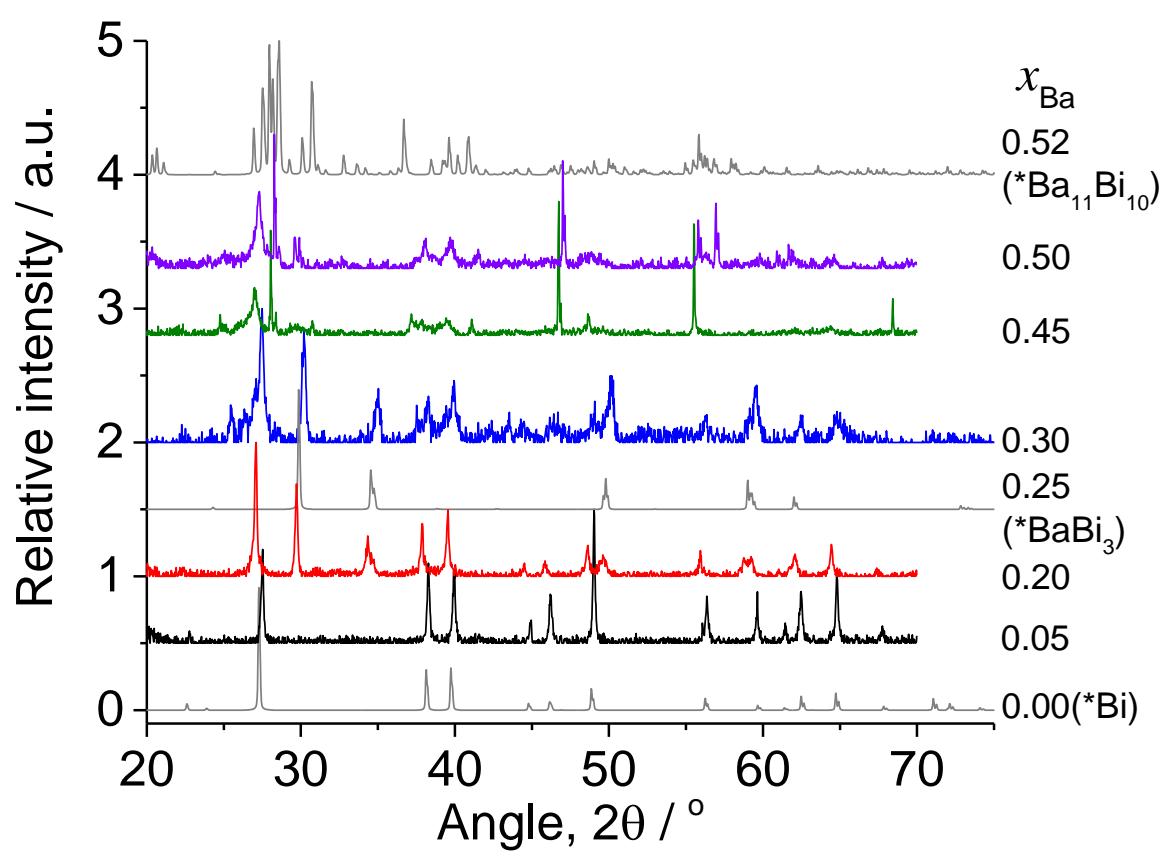

Figure 5a.

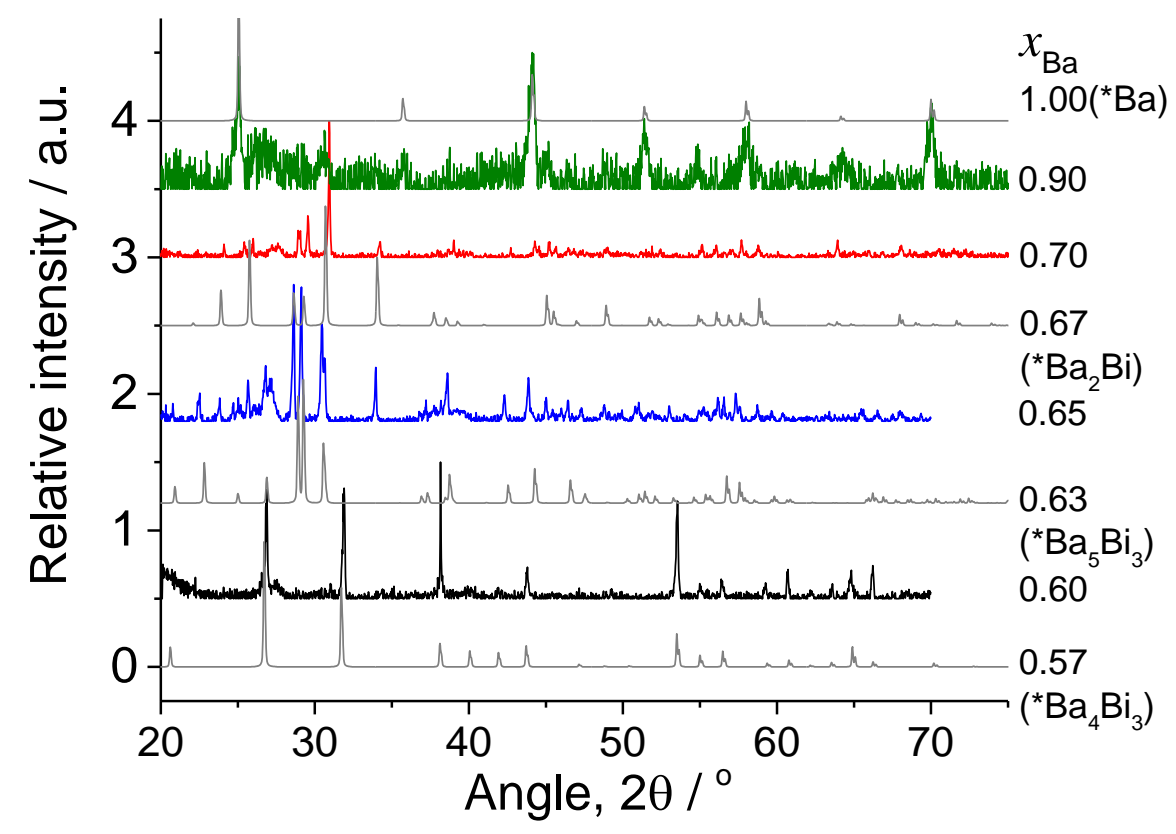

Figure 5b.

Figure 5. Representative powder XRD patterns of Ba-Bi alloys (a) $x_{\mathrm{Ba}}=0.05-0.50$ and (b) $x_{\mathrm{Ba}}=$ $0.60-0.90$, compared to the reported diffraction patterns of $\mathrm{Ba}-\mathrm{Bi}$ intermetallic compounds $\left({ }^{*}\right)$ [8-14]. 


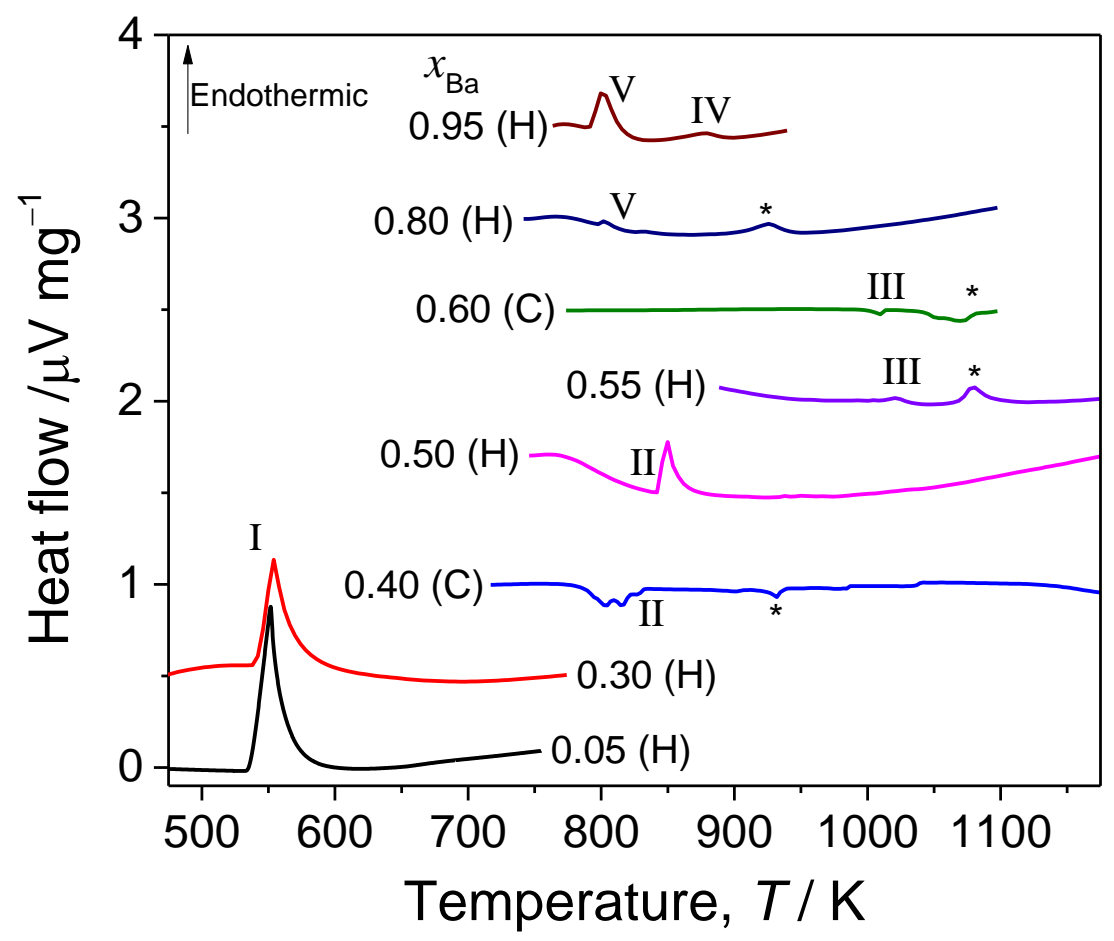

Figure 6. Representative differential scanning calorimetry data during heating $(\mathrm{H})$ or cooling $(\mathrm{C})$ cycle at $20 \mathrm{~K} \mathrm{~min}^{-1}$ for $\mathrm{Ba}-\mathrm{Bi}$ alloys $x_{\mathrm{Ba}}=0.05-0.95$, major transition temperatures are designated by Roman numerals (I-V) and by * for liquidus transitions. 


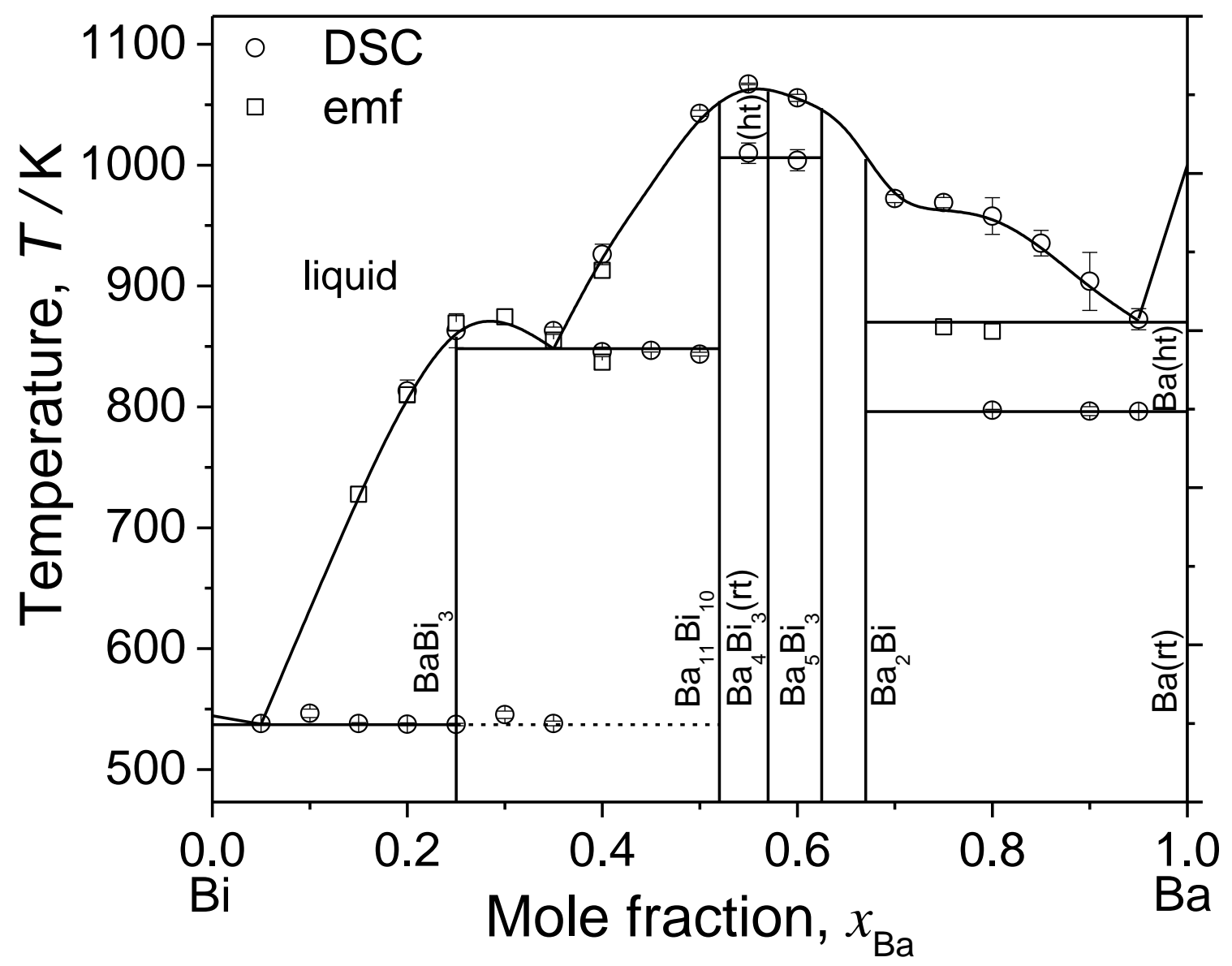

Figure 7. Revised Ba-Bi phase diagram based upon differential scanning calorimetry (DSC) and electromotive force (emf) measurements, dashed line represents metastable Bi phase up to $x_{\mathrm{Ba}}=$ 0.52 . 